\title{
Corporate Governance and Countervailing Power
}

\author{
Brian R. Cheffins ${ }^{\dagger}$ \\ August 2018 \\ Forthcoming, Business Lawyer
}

\begin{abstract}
The analysis of corporate governance has been a one-sided affair. The focus has been on "internal" accountability mechanisms, namely boards and shareholders. Each has become more effective since debates about corporate governance began in earnest in the 1970s but it is doubtful whether this process can continue. Correspondingly, it is an opportune time to expand the analysis of corporate governance. This article does so by focusing on three "external" accountability mechanisms that can operate as significant constraints on managerial discretion, namely governmental regulation of corporate activity, competitive pressure from rival firms and organized labor. A unifying feature is that each was an element of a theory of "countervailing power" economist John Kenneth Galbraith developed in the 1950 s with respect to corporations, an era when external accountability mechanisms did more than their internal counterparts to keep management in check.
\end{abstract}

Keywords: corporate governance; boards of directors; shareholder activism; regulation; unions; competition; countervailing power

JEL Codes: G34, G38, J51; K22, L13; N22

$\dagger \quad$ S.J. Berwin Professor of Corporate Law, Faculty of Law, University of Cambridge. I would like to thank Jeannie Frey and Leianne Crittenden for helpful feedback on earlier drafts. This article is part of a larger research project that will culminate in the publication of The Public COMPANY TRANSFORMED. The research has been supported by funding the Leverhulme Trust has generously provided. 


\section{INTRODUCTION}

Corporate governance can be defined as the checks and balances affecting those who

run companies. ${ }^{1}$ The topic has attracted much interest from academics and practitioners since use of the terminology became commonplace in the $1970 \mathrm{~s}^{2}$ The relevant literature is voluminous and arises from numerous disciplines, including law. ${ }^{3}$ The analysis of corporate governance has, however, been a strikingly one-sided affair. The focus has been almost exclusively on "internal" checks and balances, namely scrutiny by the board of directors and by shareholders. ${ }^{4}$ The risk of a takeover - an external accountability mechanism known as the market for corporate control ${ }^{5}$-- stands out as an exception. ${ }^{6}$ Some other external constraints on managerial discretion, such as auditors, rating organizations and the media, have also received attention in corporate governance circles. ${ }^{7}$ Other mechanisms, however, that currently operate as significant external checks on managerial discretion, or at least have operated in this manner in the relatively recent past, have been largely ignored. This article functions as a corrective to the prevailing trend.

1 Robert E. Wright, CORPORATION NATION 152 (2014).

2 Ruth V. Aguilera et al., Connecting the Dots: Bringing External Corporate Governance into the Corporate Governance Puzzle, 9 ACAD. MGMT. AnNALs 483, 484 (2015); Brian R. Cheffins, The Corporate Governance Movement, Banks, and the Financial Crisis, 16 THEO. INQ. L. 1, 2 (2015).

3 Aguilera et al., supra note 2 at 484; Brian R. Cheffins, Introduction, THE HISTORY OF MODERn U.S. CORPORATE GOVERnANCE ix, ix (Brian R. Cheffins, ed., 2011).

4 Aguilera et al., supra note 2 at 484-85; JOHn C. COFFEE, GATEKEEPERS: The PROFESSIONS AND CORPORATE GovernANCE 1 (2006); Sean J. Griffith, Corporate Governance in an Era of Compliance, 57 WILLIAM \& MARY L. REV. 2075, 2079 (2016).

$5 \quad$ Aguilera et al., supra note 2 at 496, 527-28; Henry G. Manne, Mergers and the Market for Corporate Control, 73 J. POL. ECON. 110 (1965).

6 James P. Walsh \& James K. Seward, On the Efficiency of Internal and External Corporate Control Mechanisms, 15 ACAD. MGMT. REV. 421, 433-34 (1990).

7 Aguilera et al., supra note 2 at 530-34, 537-39; COFFEE, supra note 4, 108-91, 283314. 
Such an exercise is well-timed, in that the contribution of internal constraints to managerial accountability is unlikely to increase markedly any time soon. Boards and shareholder activity have grown considerably in potency as corporate governance mechanisms over the past forty or so years. Still, while boards and shareholders have developed over this time into meaningful (if imperfect) constraints on managerial discretion, the momentum has probably stalled. With boards, for instance, there is little room left for restructuring that will bolster their monitoring capabilities. Most directors are formally independent of management and with topics where objectivity is crucial, such as the auditing function, executive compensation and the selection of nominees for board election, boards of publicly listed companies pretty much universally delegate heavily to committees staffed by independent directors. Moreover, over the past decade and a half many public companies have changed their director selection procedures in a manner that enhances shareholder influence.

As for stockholders, activist hedge funds have since the early 2000s been putting meaningful pressure on public company executives. Much has also been made of the influence investment funds designed to track major stock market indices are poised to wield due to dramatic growth in the percentage of shares they own in public companies. Major caveats are in order, however. Hedge fund interventions have been tailing off and investors have begun to withdraw their cash due to mediocre returns. With index tracking funds, a business model that favors a "hands off" approach to corporate governance suggests they are unlikely to displace a traditional reticence on the part of major institutional investors to intervene in the running of public companies.

This article does not purport to offer a comprehensive analysis of external constraints on managerial autonomy. The case that external accountability mechanisms merit closer scrutiny will instead be made by focusing on three historically important examples, namely 
state regulation of corporate activity, competitive pressure from rival firms and organized labor. A unifying feature is that John Kenneth Galbraith took account of each of them when considering "countervailing power" in the corporate context in his 1952 book American Capitalism: The Concept of Countervailing Power. ${ }^{8}$ Galbraith, who has been hailed as "the most famous, most influential, and best-connected American economist of all time," "was focusing on constraints relevant to corporations generally rather than corporate executives specifically. Nevertheless, the sources of countervailing power this article focuses on wereand are -- salient for management as well as firms.

Since the 1950s, regulation, competitive pressure from rival firms and organized labor have each operated at various times as a significant check on managerial discretion. Indeed, their impact on public company executives has sometimes been more pronounced than that of boards and shareholders. Our knowledge of the corporate governance efficacy of the countervailing power mechanisms considered here is limited as compared with boards and shareholders because of the one-sided nature of corporate governance analysis. Nevertheless, changes affecting the public company from the mid $-20^{\text {th }}$ century through to the present day indicate clearly that regulation, competitive pressure and unions have each substantially curbed managerial discretion at various junctures and thus merit further investigation as governance mechanisms.

Events occurring in the 1950s and 1960s underscore the importance of sources of countervailing power as a check on managers of large American corporations. For executives running public companies immediately following World War II, "internal” constraints on their discretion -- scrutiny by the board of directors and the shareholders -- were more

8 John KenNeth Galbraith, AmericAn CAPITALisM: The CONCEPT of COUNTERVAILING Power (1952, rev. ed., 1956).

9 James K. Galbraith, The New Industrial State, GUARDIAN, May 5, 2007. 
theoretical than actual. Boards deferred to management, at least absent a crisis. Most shares were owned directly by individual investors with tiny shareholdings and little appetite for scrutinizing companies. There correspondingly was a real risk that senior executives would take advantage of what Adolf Berle and Gardiner Means famously described in 1932 as a separation of ownership and control to exercise managerial authority in a manner that was contrary to the interests of stockholders and others closely affiliated with companies. ${ }^{10}$ Indeed, the wide discretion afforded to corporate executives meant the 1950s and 1960s were a heyday of "managerial capitalism". ${ }^{11}$

Despite the weakness of internal corporate governance mechanisms, mid- $20^{\text {th }}$ century managerial wrongdoing was rare. Executives refrained for the most part from taking a freewheeling or underhanded approach with the discretion available to them. One reason was that, with organized labor being a powerful force in numerous key industries, unions functioned as a significant constraint for management. It was also important that the mid- $20^{\text {th }}$ century heyday of managerial capitalism was simultaneously an era of "regulated

capitalism."12 Governmental action, or the threat thereof, impinged upon executive discretion in various significant ways. For instance, in industrial sectors such as telecommunications, transport and utilities regulators exercised control over entry, prices and service provision standards.

10 Adolf A. Berle \& Gardiner C. Means, The Modern Corporation \& Private PROPERTY 6, 250 (1932).

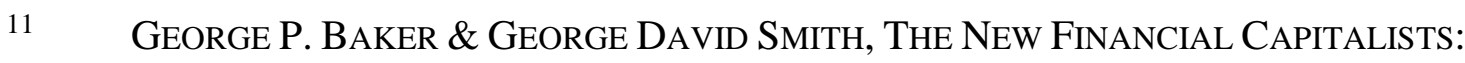
KoHLBERG KRAVIS RoBERTS AND THE CREATION OF CORPORATE VALUe 10 (1998); Ronald Dore, William Lazonick \& Mary O'Sullivan, Varieties of Capitalism in the Twentieth Century, 15(4) OXf. Rev. ECON. Pol. 102, 109 (1999); AleXANDER StYhre, The MAKIng of SHAREHOLDER WELFARE SOCIETY: A STUdy In CORPORATE GOVERNANCE 57 (2018). 12 David M. Kotz, The Rise and Fall of NeOliberal CAPitalism 6, 50-53 (2015). 
The balance between various internal and external governance mechanisms then changed over time. Under the mantle of "corporate governance" internal constraints were strengthened. Boards of directors, for instance, were reconfigured to bolster the role of "outside" directors as monitors of management. Regulatory reforms undertaken in the wake of a series of major corporate scandals in the early 2000s and the financial crisis of 2008 reinforced the process. With shareholders, the prospects for intervention improved as the ownership stakes of well-resourced "mainstream" institutional investors such as pension funds and mutual funds grew at the expense of individual stockholders. Pension funds and mutual funds failed to take command of the governance scene in the manner that seemed possible. Activist hedge funds that stepped forward in the 2000s lobbied aggressively and effectively, however, for change in the various public companies they targeted.

Regulation and organized labor, in contrast with boards and shareholders, receded as constraints on public company executives during the closing decades of the $20^{\text {th }}$ century. Unions had begun a process of pronounced, secular decline and a deregulation trend was prompting the dismantling of controls in a wide range of industries. On the other hand, competitive pressure from rival firms was growing in importance as an external constraint. As the $20^{\text {th }}$ century drew to a close, challenges from foreign and domestic rivals were eroding considerably market power that had served to insulate heretofore dominant corporations and their executives.

While the potency of internal constraints on managerial discretion has increased markedly since the managerial capitalism era, again it is doubtful whether that trend will continue. The fact that internal accountability mechanisms may have peaked as constraints on managerial discretion means it is time to reverse past analytical neglect of external constraints on managerial discretion. If little additional can be expected from boards and shareholders, then future upgrading of managerial accountability will depend largely on 
external mechanisms. In the 1980s, the market for corporate control carried much of the freight, with those running public companies being highly apprehensive about an unwelcome takeover bid. ${ }^{13}$ Hostile takeover bids, however, are now a rarity and arguably are "on life support". ${ }^{14}$ External managerial constraints Galbraith identified when describing countervailing power - regulation, competition from rivals and unions -- thus become logical candidates to investigate.

While from a corporate governance perspective Galbraith's sources of countervailing power merit greater scrutiny than they have received, none offers a magical solution to challenges associated with fostering managerial accountability. Since the secular decline affecting unions has continued to the present day, organized labor will only rarely operate as a meaningful check on managerial discretion. As for pressure from rivals, growing fears of an anti-competitive accumulation of market power by currently dominant corporations suggest competition may be on the wane as an external accountability mechanism. With regulation, deregulatory initiatives the Trump administration has undertaken indicate government action may recede in importance as a managerial constraint, at least over the short- to medium-term.

While none of the sources of countervailing power considered here is a managerial accountability silver bullet each potentially has a significant role to play in constraining executive discretion. They correspondingly merit consideration - thus far largely lacking -as part of any holistic analysis of the checks and balances affecting those who run companies.

13 Brian R. Cheffins, Corporate Governance since the Managerial Capitalism Era, 89 Bus. HIST. REV. 717, 729-30 (2015).

14 Steven M. Davidoff, With Fewer Barbarians at the Gate, A New Threat Emerges, N.Y. Times, July 31, 2013, B4. See also Matthew D. Cain, Stephen B. McKeon \& Steven Davidoff Solomon, Do Takeover Laws Matter? Evidence From Five Decades of Hostile Takeovers, 124 J. FIN. ECON. 464, 468 (2017) (empirical data). 
This article seeks to redress the situation, at least partially. It does so primarily from a historical perspective, analyzing the contribution that unions, competition from rivals and regulation made from the 1950s onwards in enhancing managerial accountability in public companies.

This article will not be offering definitive verdicts on the veracity of external accountability mechanisms. Plenty of scope remains for further analysis from empirical, legal and theoretical perspectives. Given, however, that it is unlikely that internal accountability mechanisms will become markedly more robust in the foreseeable future such analysis should begin sooner rather than later.

The article proceeds as follows. Part II focuses on the 1950s and 1960s heyday of managerial capitalism. It explains by reference to Galbraith's notion of countervailing power why wayward executives were a rarity in an era when internal accountability mechanisms were weak. Part III considers how external accountability mechanisms of which Galbraith took account were reconfigured from the mid $-20^{\text {th }}$ century through to the early 2010 s. Part IV describes how both boards and shareholders became more potent checks on public company executive discretion over the same time period, albeit often in a fitful fashion. Part V tackles the present-day situation. Reasons why internal accountability mechanisms may have peaked are canvassed. The current status of unions, pressure from rivals and regulation as external checks on managerial autonomy will also be assessed. Part VI concludes.

\section{MID-20 ${ }^{\mathrm{TH}}$ CENTURY MANAGERIAL ACCOUNTABILITY}

By the 1950s it had become the norm for large American public corporations to lack a dominant shareholder, resulting in full-time executives potentially having virtually untrammelled managerial control. These executives, as owners of only a tiny percentage of shares, had meaningful incentives to pursue their own personal agenda rather than to seek to 
boost profits and enhance shareholder returns. Nevertheless, executive misconduct was a rarity during the managerial capitalism heyday of the 1950s and 1960s. This was primarily due to external rather than internal constraints on managerial discretion.

\section{A. Ownership Separates From Control}

As the 1950s got underway the editors of Fortune hailed "the transformation of American capitalism," indicating in so doing that a key feature was that "the big modern enterprise is...run by hired management." 15 From a legal standpoint, this was not an obvious outcome. Under what has been referred to as "the received legal model of the corporation", “the board of directors manages the corporation's business and makes policy; the officers act as agents of the board and execute its decisions; and the shareholders elect the board...."16 What occurred instead was that authority to run corporations was vested in the hands of the officers (i.e. full-time executives) rather than the directors, who had delegated their managerial power. ${ }^{17}$ Shareholder election of directors simultaneously verged toward an empty formality. This was because incumbent executives could dominate through control of the corporations they ran the solicitation of proxies, the written documentation most shareholders would use to cast their votes. ${ }^{18}$

Share ownership patterns reinforced managerial dominance. By the mid- $20^{\text {th }}$ century the typical large public corporation lacked a shareholder, or tight coalition of shareholders, who owned a large enough stake to dictate the outcome of most, if not all, shareholder votes. There correspondingly was a separation of ownership and control. This is a pattern that has

15 Editors (Fortune), USA: The PERMAnEnt Revolution 65, 67, 78 (1951). 16 Melvin Aron Eisenberg, The Structure of the Corporation: A Legal ANALYSIS 1 (1976).

17

Id. at 139-41.

$18 \quad I d$. at 97-104. 
been closely associated with Adolf Berle and Gardiner Means and their 1932 classic The Modern Corporation and Private Property. ${ }^{19}$ Indeed, the term "Berle-Means corporation" (or "Berle and Means corporation") has been adopted as shorthand for large firms with widely dispersed share ownership. ${ }^{20}$ Data Berle and Means compiled, however, did not match up fully with their rhetoric. They found that as of 1930 management control, defined as a lack of evidence of a shareholder with an ownership stake of 20 percent or more, only prevailed in a minority (88) of the 200 largest non-financial companies ranked by assets. ${ }^{21}$

While a separation of ownership and control was not the norm as of the early 1930s, matters were evolving in that direction. The New York Times said in 1955 of public companies and their executives:

"A generation or so ago, most corporations were held by small groups of investors. Often as not, members of the founding family held the majority of shares. Then came in succession the Great Depression, high taxes on incomes and estates and the need for new capital in a rapidly growing economy. Result: today, the stock of many companies is widely distributed among thousands or even hundreds of thousands of shareholders.

19 BERLE AND MEANS supra note 10.

20 See, for example, Stephen M. Bainbridge, The Politics of Corporate Governance, 18 HARV. J.L. \& Pub. Policy 671, 674 (1995); Rafael La Porta, Florencio López-de-Silanes, Andrei Shleifer \& Robert Vishny, Corporate Ownership Around the World, 54 J. FIN. 471, 474 (1999); Sofie Cools, The Real Difference in Corporate Law between the United States and Continental Europe: Distribution of Powers, 30 DEL. J. CORP. L. 697, 698 (2005). The term was coined by Mark Roe -- Mark J. Roe, A Political Theory of American Corporate Finance, 91 Colum. L. ReV. 10, 11 (1991).

21 BERLE \& MEANS supra note 10 at 98-101, 106. Berle and Means actually classified $881 / 2$ companies as being under management control. The half was awarded due to a "special situation", namely the utility Chicago Rys. Co. being in receivership (at 101). 
Management, in effect, has become a high-priced employe(e)."22

The Times' characterization of changes affecting ownership patterns in large corporations reflected the general consensus. Harvard economist Edward Mason observed in 1959 "(a)lmost everyone now agrees that in the large corporation, the owner is, in general a passive recipient; that typically control is in the hands of management; and that management normally selects its own replacements." 23 At that point there was an absence of reliable data confirming the general consensus regarding ownership patterns. ${ }^{24}$ Empirical studies carried out in the 1960s and 1970s, however, largely corroborated assumptions that a separation of ownership and control was the norm in large business enterprises. ${ }^{25}$

B. The Possibility of Abuse

In a corporation lacking dominant shareholders management will necessarily own only a small percentage of the outstanding shares. ${ }^{26}$ The executives in turn will, as shareholders, receive only a small proportion of the returns derived from the profit-enhancing activities they engage in on behalf of the company. They correspondingly will have an incentive to further their own interests at the expense of other investors. ${ }^{27}$

With it becoming the norm in the mid-20 $0^{\text {th }}$ century for large U.S. corporations to lack dominant stockholders, and with the scope that exists for abuse of managerial discretion

22 Richard Rutter, Proxy Wards Shed No Gore, Much Ink, N.Y. TIMES, May 24, 1955, 44.

23 Edward S. Mason, Introduction in THE CORPORATION IN MODERN SOCIETY 1, 4 (Edward S. Mason ed., 1959).

$24 \quad$ Brian Cheffins \& Steve Bank, Is Berle and Means Really a Myth?, 83 Bus. Hist. REV. 443, 456 (2009).

25 Id. at 468-69 (2009) (see Appendix 2).

26 George J. Stigler and Claire Friedland, The Literature of Economics: The Case of Berle and Means, 26 J.L. \& ECON. 237, 238 (1983).

27 Cheffins, supra note 3 , xi. 
when share ownership is diffuse, the separation of ownership and control constituted what would be referred to subsequently as "the core fissure" in American corporate governance. ${ }^{28}$ As early as 1932 Berle and Means were asking readers "have we any justification for assuming that those in control of a modern corporation will also choose to operate it in the interests of their owners?"29 Mason indicated similarly in 1959 "the independence of corporate management from any well-defined responsibility to anyone...carries with it the possibilities of abuse." 30

C. Prosperity and Propriety

While it was well-known during the 1950s and 1960s that the separation of ownership and control in large corporations posed risks, few of whatever fears existed were borne out. "Prosperity was the dominant theme of the postwar era" 31 as the U.S. economy grew smartly at a rate of 3.7 percent annually between 1948 and $1973 .{ }^{32}$ Large public companies flourished in this milieu. The S\&P 500 stock market index increased more than 650 percent between January 1950 and December $1968 .{ }^{33}$

There were during the 1950s and the 1960s some newsworthy examples of unethical managerial behaviour. ${ }^{34}$ Nevertheless, amidst considerable corporate success, the dominant

28 Mark J. Roe, The Inevitable Instability of American Corporate Governance, 1 CoRP. Gov. L. REV. 1, 2 (2005).

29 BERLE \& MEANS, supra note 10, 113.

$30 \quad$ Mason, supra note 23, 11.

31 Wyatt Wells, American Capitalism, 1945-2000: CONTINUity AND Change From MASS PRODUCTION TO THE INFORMATION SOCIETY 27 (2003).

32 Nitin NOHRIA, DAVIS DYER \& FrEDERICK DALZELl, ChANGING ForTUNES: REMAKING THE INDUSTRIAL CORPORATION 38 (2002).

33 During the 1950s and 1960s, the S\&P 500 peaked at 109.37 in December 1968. It opened at 16.66 in January 1950. See $S \& P$ 500/Historical Data, available at https://finance.yahoo.com/quote/\%5EGSPC/history/ (accessed May 14, 2018).

34 Cheffins, supra note 13, 721. 
image of public company leadership during the heyday of managerial capitalism was that of executives exercising corporate power in a self-restrained and socially responsible manner. ${ }^{35}$ For instance, while Adolf Berle expressed concerns in 1932 that those controlling public companies would abuse the discretion available to them, in 1959 he observed "(c)onsiderable progress has been made in eliminating the spasms of dishonesty or near dishonesty which too often disgraced our system in the past decades." ${ }^{36}$ A lengthy 1966 New York Times essay on big business noted that " $(\mathrm{t})$ he big story is not really one of callous exploitation or crass irresponsibility" and suggested that "articulate segments of the American public seem at times to show more faith in United States Steel than the United States Senate."37 The retrospective verdict has similarly been that the mid- $20^{\text {th }}$ century was characterized by managerial propriety. ${ }^{38}$ For instance, law professors William Black and June Carbone have said of the 1950s and 1960s that the "era produced a high degree of corporate honesty and....(1)arge-scale corporate scandals....largely disappeared." 39

D. Weak Internal Constraints

Given the dearth of executive wrongdoing when managerial capitalism was in the ascendancy and given that present-day analysis of corporate governance revolves primarily around internal constraints on managerial discretion, namely boards and shareholders, a

35 Gabriel Kolko, Wealth And Power in America: An ANALysis of Social Class AND INCOME DISTRIBUTION 55 (1962) (the author of this study dissented from the consensus). 36 Adolf A. Berle, Power Without Property: A New DeVelopment in American POLITICAL ECONOMY 3 (1959).

37 Andrew Hacker, A Country Called Corporate America, N.Y. TIMES, July 3, 1966, Sunday Magazine, 9.

38 See, for example, DAVID SKEEL, ICARUS IN THE BOARDROOM: THE FUNDAMENTAL FLAWS IN CORPORATE AMERICA AND WHERE THEY CAME From 106 (2005); Mark Mizruchi \& Howard Kimeldorf, The Historic Context of Shareholder Value Capitalism 17 POL. POWER \& SOC. THEORY 213, 216 (2005).

39 William K. Black \& June Carbone, Economic Ideology and the Rise of the Firm as a Criminal Enterprise, 49 AKRON L. REV. 371, 388 (2016). 
logical inference to draw would be that during the 1950s and 1960s directors and/or stockholders were making substantial efforts to keep public company executives in check.

This was not the case. Neither boards nor shareholders were likely to intervene to forestall or correct managerial missteps, absent a crisis.

1. Boards

Boards do not run public companies despite being legally empowered to do so under state corporate law. Executives the directors appoint do so, exercising delegated managerial authority. ${ }^{40}$ From a governance perspective, the obvious role for boards to play is to keep the executives in charge in check, with directors detached and independent from management being the logical candidates to foster accountability due to their objectivity. ${ }^{41}$ This "monitoring" model of the board gained wide currency during the 1970s. ${ }^{42}$ The idea that the board could and should act as a managerial "watchdog" was by no means unfamiliar, however, during the 1950s and 1960s. ${ }^{43}$ In 1956 the New York Stock Exchange (NYSE) required companies listed on the Exchange to have at least two independent directors on the board. ${ }^{44}$ By the late 1950 s a consensus was developing amongst experts on boards that ideally a majority of directors of a public company should be individuals not holding

\footnotetext{
$40 \quad$ Supra note 17 and related discussion.

41 BRIAN R. CHEFFINS, COMPANY LAW: THEORY, STRUCTURE AND OPERATION 605 (1997).

42 Lawrence E. Mitchell, The Trouble With Boards, PERSPECTIVES On CORPORATE
} Governance 17, 31-32 (F. Scott Kieff \& Troy A. Paredes, eds., 2010). See also infra notes 239-40 and accompanying text.

43 See, for example, MELvin T. COPELAND \& ANDREW R. TOWL, THE BoARD OF DIRECTORS AND BUSINESS MANAGEMENT 146 (1947) ("One of the most common theories about directors... is that a main task of directors is to serve as watchdogs, policing the executives....").

$44 \quad$ Brian R. Cheffins, Steven A. Bank and Harwell Wells, Shareholder Protection Across Time, 68 U. FLA. L. REV. 691, 744 (2017). 
executive posts. ${ }^{45}$ The pattern was simultaneously becoming increasingly prevalent in practice. Before the 1950s drew to a close executive directors were outnumbered on the board in a majority of leading manufacturing companies and in most of the largest firms outside the industrial sector. ${ }^{46}$

Despite growing outside director representation, the consensus during the 1950 s and 1960s was that only a crisis would preclude boards from deferring to the management team. ${ }^{47}$ What Berle referred to in 1959 as "obsolete processes of selection" of directors ${ }^{48}$ lent credence to skepticism about boards. Under state corporate law, the shareholders had the right to elect the directors. ${ }^{49}$ Practically speaking, however, the choice shareholders had was limited on the vast majority of occasions to voting on a single slate of nominees the incumbent board selected. ${ }^{50}$ These nominees were in turn almost inevitably endorsed by huge majorities as shareholders refraining from attending stockholder meetings in person sent in proxy documentation authorizing the voting of their shares by those already running the

45 Mabel Newcomer, The Big Business Executive: The Factors That Made Him 29-30 (1955) (describing the views of the "majority of those writing on the subject"); THE DiRECTOR LOOKS AT His Job 82 (Courtney C. Brown \& E. Everitt Smith, eds., 1957). $46 \quad$ Managers Fade as Directors, Bus. WK., June 27, 1959, 72 (citing a survey of 925 companies); John Chamberlain, Why it's Harder and Harder to Get a Good Board, FORTUNE, Nov. 1962, 108 (citing a study by Fortune); MYles L. MACE, DireCTORS: MYTH AND REALITY 111-12 (1971) (providing data for manufacturing companies for 1953, 1958, 1961 and 1966).

47 DiRECTOR LOOKS, supra note 45, 46; HERRYMON MAURER, GREAT ENTERPRISE: GROWTH AND BEHAVIOR OF THE BIG CORPORATION 201 (1955); J.M. JURAN \& J. KEITH LOUDEN, THE CORPORATE DIRECTOR 293 (1966).

48 BERLE, supra note 36, 108.

49 HAROLD KoONTZ, The BoARd of DiRECTORS AND EFFECTIVE MANAGEMENT 76 (1967). 
company. ${ }^{51}$ With this arrangement, caustically described as a "communist ballot" 52 and "a total farce", ${ }^{53}$ being nominated by the board was the key to becoming and remaining a director. $^{54}$

By the 1980s it would become commonplace for boards of public companies to delegate the task of selecting board candidates to a nomination committee comprised of independent directors. ${ }^{55}$ Such committees were a rarity, however, in the 1950s and 1960s. ${ }^{56}$ It instead usually fell to the chief executive to take the lead with the selection of board candidates. ${ }^{57}$ This occurred despite awareness that it was less than ideal for chief executives to recruit only directors they would be happy to work with. ${ }^{58}$

\section{Shareholders}

Richard Eells, in a 1962 analysis of corporate "government" (he was a very early adopter of the term "corporate governance"), specifically identified shareholders as an internal mechanism that could stifle the counterproductive exercise of managerial power. ${ }^{59}$ He said, however, that "attempts...to activate shareholder control of management have had

51 Mortimer M. Caplin, Proxies, Annual Meetings and Corporate Democracy: The Lawyer's Role, 37 VA. L. REV. 653, 654-55 (1951).

52 J.A. LIVINGSTON, THE AMERICAN STOCKHOLDER 46 (1958).

53 Eugene V. Rostow, To Whom and for What Ends is Corporate Management Responsible? in THE CORPORATION, supra note 23, 46, 54.

54 Wilbert E. Moore, The CONduct of the Corporation 9 (1962).

55 JEREMY BACON, MEMBERSHIP AND ORGANIZATION OF CORPORATE BOARDS 33 (1990) (43 percent of a sample of large corporations had such a committee as of 1981, with the proportion increasing to 49 percent by 1989).

$56 \quad$ JURAN \& LOUDEN, supra note 47, 218; Brian R. Cheffins, Delaware and the Transformation of Corporate Governance, 40 DEL. J. CORP. L. 1, 33, 39 (2015).

$57 \quad$ MACE, supra note 46, 188; KoONTZ, supra note 49, 227.

58 DiRECTOR LOOKS, supra note 45, 53-54; KOONTZ, supra note 49, 227.

59 RichARD EELls, The GOVERNMENT OF CORPORATIONS 23, 253 (1962). On his being a pioneer user of the term "corporate governance", see LAURA F. SPIRA \& JUDY SLINN, THE CADBURY COMMITTEE: A HistORY xx (2013). 
insignificant results" and that "( $\mathrm{t}$ )he controls of the corporate electorate - the stockholders over board and management are severely limited in the large public-issue corporation." 60 Others concurred. Shareholders in the managerial capitalism era were described as "passive", ${ }^{61}$ and "an apathetic bunch"62 that played "no active role at all.,"63

It was hardly surprising the prospects for meaningful shareholder governance involvement were bleak during the 1950s and 1960s. "Household" investors - primarily individuals buying and selling securities for their own personal account -- collectively owned most of the shares in publicly traded companies (Figure 1). ${ }^{64}$ Shareholders of this sort typically lack the aptitude, resources and firm-specific information needed to intervene productively in corporate affairs. ${ }^{65}$ Private ("retail") investors have little incentive to step forward in any case, given the hassle involved and given that the typical individual stockholder owns a tiny stake and thus will only benefit trivially in relation to any share price increase associated with a successful intervention. ${ }^{66}$ They indeed were caustically labelled in 1967 "20 Million Careless Capitalists." 67

Figure 1: U.S. Corporate Stock Held by Households and Institutions, 1950-1970

\footnotetext{
$60 \quad$ EELLS, supra note 59, 23, 199.

61 BERLE, supra note $36,74$.

62 Peter B. Greenough, Stockholders Lax as Voters, Boston GloBe, March 19, 1964,

20.

63 MAURER, supra note 47, 3.

64 "Households" is the residual term used by the Federal Reserve, which compiles data on holders of corporate stock, to categorize owners of shares. See Marcel Kahan \& Edward Rock, Embattled CEOs, 88 TEX. L. REV. 989, 996, n. 24 (2010).

65 Cheffins, supra note 3 , xix.

$66 \quad I d$.

67 Carter F. Henderson \& Albert C. Lasher, 20 Million Careless Capitalists (1967).
} 


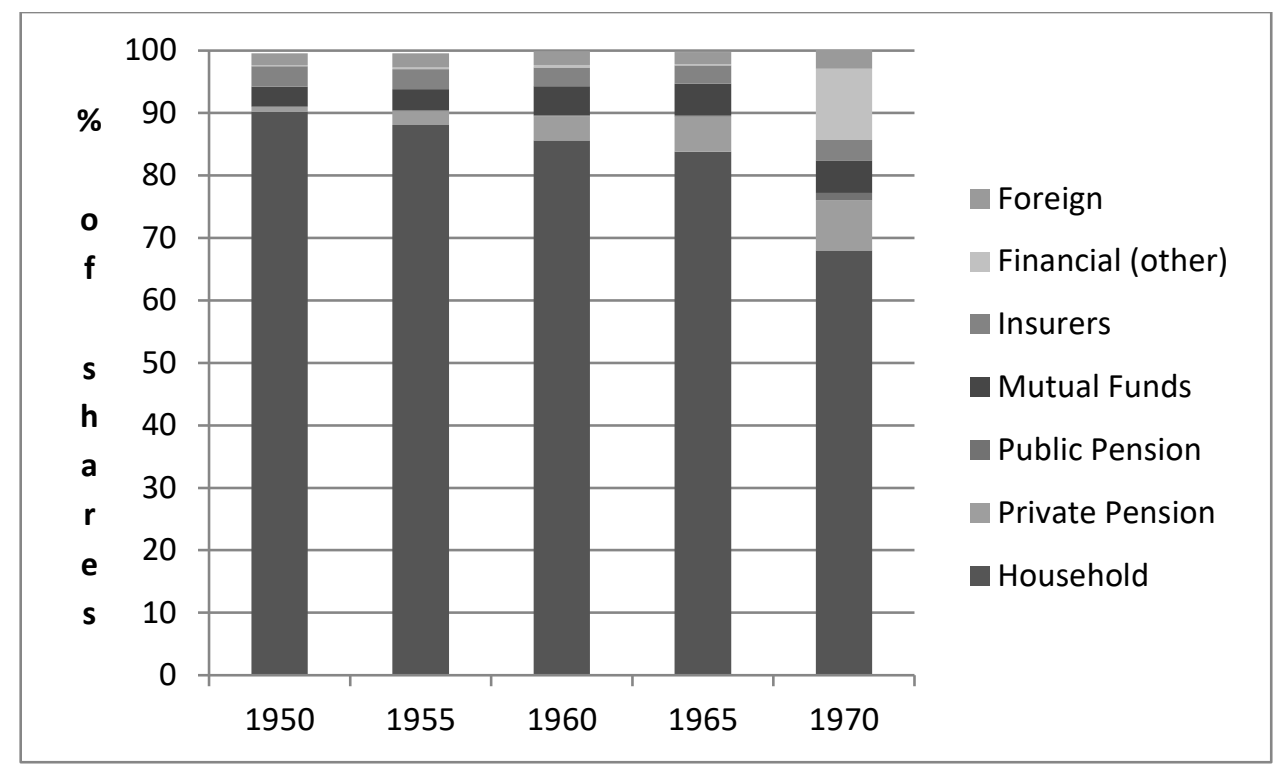

Source: O’Sullivan $(2000)^{68}$

While private stockholders dominated share ownership throughout the 1950s and 1960s, their institutional counterparts were growing in importance (Figure 1). Suggestions followed that mainstream institutional investors such as mutual funds and pension funds might function as a source of managerial discipline in a way that private shareholders could not. For instance, in 1959 John Kenneth Galbraith identified the accumulation of shares by institutional shareholders as "the one looming threat to the autonomy of the professional managers." ${ }^{69}$ However, institutional investors, setting a pattern that would prevail over the next few decades, failed to step forward to the extent that seemed possible. A 1965 study of institutional shareholders characterized them as "silent partners" and indicated "(f)or the most part, institutions are investors not controllers." 70

\section{MARY O'SUllivan, CONTESTS FOR CORPORATE CONTROL: CORPORATE GOVERnANCE AND ECONOMIC PERFORMANCE IN THE UNITED STATES AND GERMANY 156 (2000).}

69 J.K. Galbraith, The Self-Appointed Tenants in the Executive Suite, N.Y. TIMES, Sept. 6, 1959, Book Review, 3. See also David R. Francis, Large Shareholders Press for Voice in Management, CHRISTIAN SCI. MONITOR, Nov. 18, 1966, 20.

70 DAniel J. BAum \& Ned B. Stiles, The Silent PARTners: Institutional Investors AND CORPORATE CONTROL 68 (1965). 


\section{E. Galbraith and Countervailing Power}

While the primary theme in Berle and Means' The Modern Corporation and Private Property was the separation of ownership and control in large business enterprises it addressed others. ${ }^{71}$ One was documenting a growing concentration of economic power in major corporations. ${ }^{72}$ Indeed, the most widely-quoted statistic in the book was that the largest 200 non-financial American corporations accounted for half of all corporate wealth and 43 percent of all corporate income. ${ }^{73}$

Consistent with an American tradition of suspicion of private business power, following World War II the dominance of large enterprises prompted concern among many. ${ }^{74}$ The uneasiness was somewhat paradoxical, however, given the robust performance of the American economy. ${ }^{75}$ How was it that an economy could be so successful if large business enterprises that were a potent source of apprehension were simultaneously dominating that economy? John Kenneth Galbraith sought to resolve the paradox in his 1952 book American Capitalism, a revised edition of which was published in $1956 .^{76}$

Galbraith acknowledged that under mainstream economic theory where business was operating in a market setting involving many buyers and many sellers the operation of competitive forces "solved the operating problems of the economy." epochal investigation" of Berle and Means and subsequent studies that had prompted "wide

\footnotetext{
71 Thomas K. McCraw, Berle and Means, 18 ReV. AM. Hist. 578, 584 (1990).

72 BERLE \& MEANS, supra note 10, 18-46; Stigler and Friedland, supra note 26, 239.

73 McCraw, supra note 71, 583.

74 GALBRAITH, supra note 8, 21.

75 Id. at 15-16; supra notes 31-32 and related discussion; JAMES RONALD STANFIELD \& JACQUELINE BLOOM STANFIELD, JOHN KENNETH GALBRAITH 70, 72 (2011).

76 GALBRAITH, supra note 8.

$77 \quad$ Id. at 37 .
} 
acceptance" of "the notion that there was extensive concentration in American industry,"78 Galbraith maintained "a basic supposition of capitalism - the supposition that it was socially efficient" was thrown into question. ${ }^{79}$ Galbraith also noted that with large corporations having achieved considerable prominence fears of corporate overreach would inevitably arise, saying "that it was easy to suppose that since competition had disappeared, all effective restraint on private power had disappeared." $" 80$

Yet the American economy was performing well. Moreover, Galbraith acknowledged that while the data on corporate concentration implied "the American is controlled, livelihood and soul, by the large corporation; in practice he seems not to be completely enslaved." ${ }^{81}$ Galbraith's explanation why there was economic prosperity and continued personal autonomy despite the prevalence of large, seemingly omnipotent corporations was that "new restraints on private power" existed in the form of "countervailing power." 82 He maintained that "as a common rule, we can rely on countervailing power to appear as a curb on economic power." 83 The consequent balancing served in turn as a means of stabilization and legitimation in the post-World War II economic order. ${ }^{84}$

Galbraith, in developing his theory of countervailing power, focused to a significant extent on buyers and sellers of a product or service. He maintained powerful sellers would
$78 \quad$ Id. at 50.
$79 \quad I d$. at 62 .
$80 \quad$ Id. at $124-25$.
$81 \quad I d$. at 123.
82 Id. at 125; David B. Audretsch, Joseph Schumpeter and John Kenneth Galbraith: Two Sides of the Same Coin?, 25 J. EvOLUTIONARY ECON. 197, 204-5 (2015).

83 GALBRAITH, supra note 8, 127.

84 John W. Cioffi, Fiduciaries, Federalization, and Finance Capitalism: Berle's Ambiguous Legacy and the Collapse of Countervailing Power, 34 SEATTLE U. L. Rev. 1081, 1087 (2011). 
prompt the growth of powerful buyers and vice versa, such as large automobile companies counteracting dominant steel mills. ${ }^{85}$ Galbraith's sources of countervailing power were not restricted, however, to a matching up of powerful sellers and buyers. Indeed, he suggested "(t)he operation of countervailing power is to be seen with the greatest clarity in the labor market." G6 Galbraith had organized labor in mind here, suggesting that "one finds the strongest unions in the United States where markets are served by the strongest corporations." ${ }^{87} \mathrm{He}$ argued the pattern existed partly because "the strength of the corporations" involved made "it necessary for workers to develop the protection of countervailing power." ${ }^{88}$ Also significant was that the firms in question frequently had oligopolistic control of their industries and were prospering accordingly. Through a union a powerful company's employees could more effectively "share in the fruits of the corporation's market power." 89

Though Galbraith took pains to emphasize how the prevalence of large corporations had compromised the operation of competitive forces in the economy, pressure from rivals within an industry remained an element of his analysis of countervailing power in the corporate realm. He said there was a "convention against price competition" due to "the typical modern market of few sellers." $" 90$ Competition nevertheless remained a "regulator of economic activity."91 As Galbraith noted, when there were numerous buyers and sellers in a

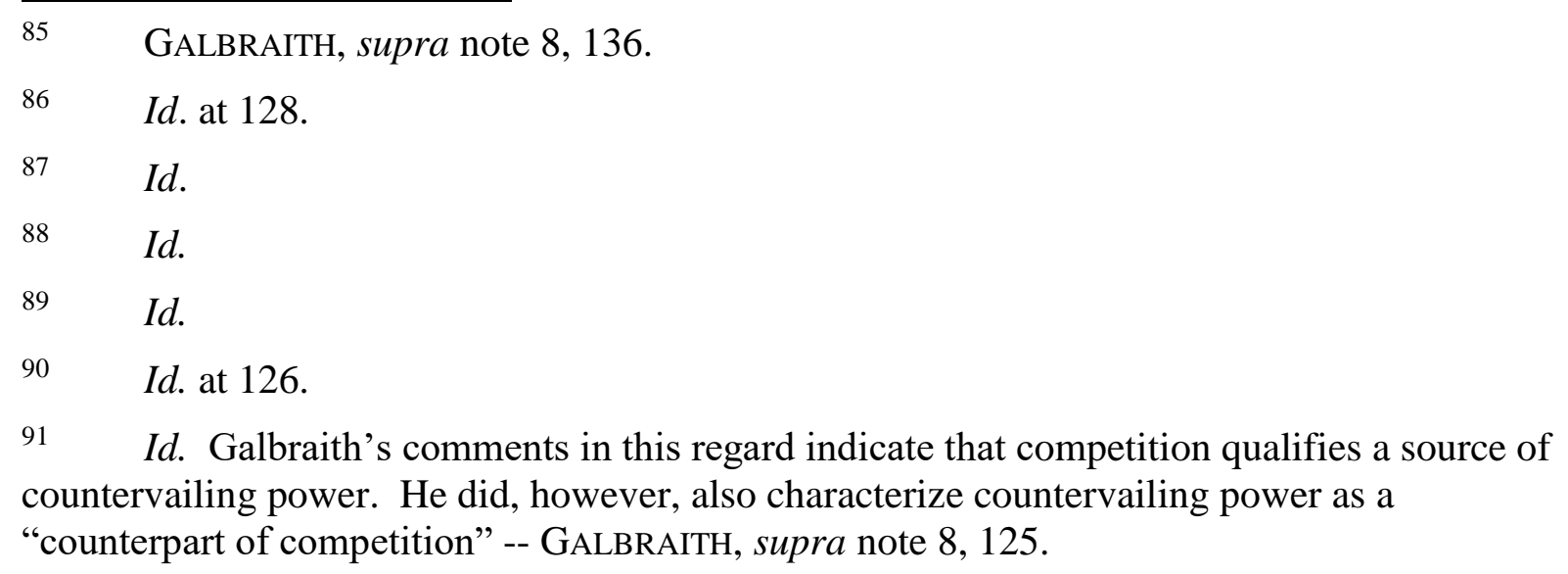


particular market "(t)he active restraint is provided by the competitor who offers, or threatens to offer, a better bargain." 92 He indicated that "(t)here are still important markets where the power of the firm as (say) a seller is checked or circumscribed by those who provide a similar or a substitute product or service." 93

Galbraith also treated the state as an important facet of his world of countervailing power. He argued that where countervailing powers were emerging in response to corporate dominance, government should foster their development because doing so "strengthens the capacity of the economy for autonomous self-regulation and thereby lessens the amount of

over-all government control or planning that is required or sought."94 Galbraith maintained that this in fact was being done to a substantial degree, suggesting "the support of countervailing power has become in modern times the major peacetime function of the federal government." 95 He cited as an example federal legislation enacted during the mid1930s that put unions on a sound organizational footing and thereby helped to foster a dramatic increase in union membership. ${ }^{96}$ Galbraith also drew attention to antitrust law, suggesting that steps taken to preclude mergers that would result in monopoly power and to dismantle existing monopolies should be beneficial because it was "much easier for countervailing power to break into a position of market strength maintained by an imperfect coalition of three, four, or a dozen firms than in a position held by one firm."97

\footnotetext{
92 GALBRAITH, supra note 8, 126.

$93 \quad I d$.

$94 \quad I d$. at 165.

$95 \quad I d$. at 151.

$96 I d$. at 150. On the legislation and its impact, see George David Smith \& Davis Dyer, The Rise and Transformation of the American Corporation in THE AMERICAN CORPORATION TODAY 28, 49-50 (Carl Kaysen, ed., 1996); MARK S. MizRUCHI, THE FrACTURING OF THE AMERICAN CORPORATE ELITE 81-82, 87-88 (2013).

GALBRAITH, supra note 8, 159.
} 
Galbraith, in citing unions, pressure from rivals and state intervention in the context of countervailing power, was identifying constraints relevant for corporations. He was not focusing, as such, on limitations on managerial discretion. Still, links existed. Antitrust law, for instance, could have direct personal implications for executives. Galbraith said that "(a)s the antitrust laws are now financed and enforced, the head of any large American corporation must count on the possibility of being hailed into court at least once in his lifetime."98

More generally, Galbraith implicitly equated countervailing power constraints on corporations as constraints on their executives. For Galbraith managerial accountability (or lack thereof) was not an analytical priority because he did not think that purely self-serving goals motivated corporate executives substantially. Corporate success, defined by firm size, instead largely correlated with managerial success. Galbraith argued "(t)he income of a businessman is no longer a measure of his achievement; it has become a datum of secondary interest." 99 The key metric instead was power, which was the benchmark for prestige in the business world. 100 "The size of the corporation", in turn was the "rough index of the power the individual exercises," with "ducal honors" in "the business peerage" going to those who ran the largest firms. ${ }^{101}$ Given the alliance of interest between large public companies and their executives, it followed that countervailing power that limited the growth and authority of corporations would simultaneously be a check on the executives in charge of those firms. Galbraith thus implicitly treated unions, regulation and competition as external managerial accountability mechanisms as part of his countervailing power characterization of American capitalism.

$\begin{array}{ll}98 & I d . \text { at } 74 . \\ 99 & I d . \text { at } 39 . \\ 100 & I d . \\ 101 & I d . \text { at } 40 .\end{array}$


F. Countervailing Power During the 1950s and 1960s

In 1959 Adolf Berle, having acknowledged that American corporations had recently been relatively free from managerial excess, said this had not occurred due to the arrival of "saints" but rather due to external checks public opinion shaped. ${ }^{102}$ Economist Robert Eagly struck a similar chord in an essay published the same year in which he said "a new motivational ethos" did not explain why, in contrast with the situation in 1900, "American big business operates with a keen awareness of its human environment." 103 Eagly cited instead "the changing institutional environment within which big business operates." 104

Norton Long, a political scientist also writing in 1959, recognized in tandem with Eagly that taking into account the environment within which public companies operated was required to explain how corporate executives were conducting themselves. Long accepted that the typical public company executive "has a concern for harmony and the avoidance of trouble that sets him apart from his predecessors" and noted "present managerial behaviors give rise to doubt as to unrestrained corporate power" 105 The explanation for this state of affairs, according to Long, was that "management is surrounded by a network of constraints and fears" but he acknowledged the network's operation was "as yet an unwritten chapter in industrial sociology."106 With the benefit of hindsight, two sources of countervailing power Galbraith identified, unions and state intervention (including the threat thereof), were foremost among the "network of constraints" relevant for public company executives during

\footnotetext{
102 BERLE, supra note 36, 22.

103 Robert Eagly, American Capitalism: A Transformation?, 33 Bus. Hist. ReV. 549, 567 (1959).
}

$104 \quad I d$.

105 Norton E. Long, The Corporation, its Satellites, and the Local Community in THE CORPORATION, supra note 23, 202, 205, 209.

106

Id. at 209. 
the 1950s and 1960s. Discipline arising from corporate rivals was, at least for the moment, of secondary importance.

\section{Competition}

Competing firms theoretically could have been a potent feature of the "network of constraints" corporate executives had to navigate during the 1950s and 1960s. There certainly was awareness that the fear of losing out to rivals functioned as a disciplinary mechanism in the corporate context. For instance, the 1965 study of institutional investors that characterized them as "silent partners" explained a general absence of "corporate plundering" partly on the basis that "(w)here competition exists, as it does throughout most of the economy, the desire to excel undoubtedly serves to prevent corporate abuse."107

While the 1965 study presupposed meaningful competition was the norm throughout the American economy, Galbraith disagreed. Though he acknowledged that "(c)ompetition still plays a role" in influencing corporations, he said that, given "the typical modern market of few sellers," it was "not the only or even the typical restraint on the exercise of economic power."108 Berle, Means and numerous other scholars concurred with Galbraith regarding competition's attenuated impact on business decision-making, as they assumed that dominant firms vested with considerable market power were standard in the American economy. ${ }^{109}$ Similarly, the prevailing view among academics analyzing the 1950s and 1960s retrospectively has been that it was commonplace for a small number of powerful companies

$107 \quad$ BAUM \& STILES, supra note 70, 9.

108 Supra note 90 and accompanying text; GALBRAITH, supra note 8, 126.

109 Berle, supra note 36, 89; GARDINER C. MEANS, The CORPORATE REVOLUTION IN AMERICA: ECONOMIC REALITY VS. ECONOMIC THEORY 162-65 (1962); Carl S. Kaysen, The Social Significance of the Modern Corporation, 47 AMER. ECON. REV. 311, 314 (1957). 
to dominate an industry. ${ }^{110}$ For corporate executives of dominant firms operating under oligopolistic conditions, the market power from which the corporations would have benefitted would have muted considerably the potency of competition as a managerial accountability mechanism.

\section{Unions}

In the same way that there was general concurrence with Galbraith that competitive pressure rivals imposed was not as potent a constraint on corporations and their executives as was theoretically possible, his argument that unions were a meaningful source of countervailing power commanded substantial support. The 1965 study of institutional investors that characterized them as silent partners cited the fact that unions were a force to be reckoned with as one explanation for the faithful stewardship the vast majority of postWorld War II executives had demonstrated. ${ }^{111}$ Various contemporaries indeed specifically endorsed Galbraith's views on organized labor. ${ }^{112}$ His argument that unions were a meaningful source of countervailing power with respect to large companies during the mid$20^{\text {th }}$ century gained adherents subsequently as well. ${ }^{113}$

While unions were in the corporate context a meaningful source of countervailing power during the 1950s and 1960s, the influence of organized labor operated, as political

110 See, for example, Smith \& Dyer, supra note 96, 51; Harwell Wells, "Corporation Law is Dead": Heroic Managerialism, Legal Change, and the Puzzle of Corporation Law at the Height of the American Century, 15 U. PA. J. Bus. L. 305, 317-18 (2013); Douglas M. EICHAR, THE RISE AND FALL OF CORPORATE SOCIAL RESPONSIBILITY 188, 218 (2015).

111 BAUM \& STILES, supra note 70, 7.

112 See, for example, Michael D. Reagan, The MANAgEd ECONOMY 145 (1963); Adolf A. Berle, Power 223-31 (1967); DAVID Finn, The CORPORATE OligarCH 43-44 (1969).

113 Mizruchi and Kimeldorf, supra note 38, 215-16; Smith \& Dyer, supra note 96, 50; Thomas A. Kochan, The American Corporation as an Employer: Past, Present, and Future Possibilities in AMERICAN CORPORATION, supra note 96, 242, 244. 
scientist Michael Reagan observed in 1963, "within a circumscribed scope of affairs and where unions exist." 114 As for the "scope of affairs", key aspects of managerial discretion remained unaffected by union power. Distinguished business historian Alfred Chandler said unions

“directly affected only one set of management decisions - those made by middle managers relating to wages, hiring, firing and conditions of work. Such decisions had only an indirect impact on the central ones that coordinated current flows and allocated resources for the future." 115

With the qualification about where unions existed, in the 1950s and 1960s union members never made up a majority of the workforce. Instead, union density (the proportion of workers who are unionized) peaked at 35 percent in 1954 and declined steadily to 27 percent by $1970 .^{116}$ The impact organized labor had on managerial discretion likely was greater than these figures suggest due to non-union firms nervous about unionization adjusting their labor relations practices to see off the threat. ${ }^{117}$ More generally, despite the caveats, the endorsements of Galbraith's analysis of unions indicate executives running large firms during the 1950s and 1960s often thought of organized labor as a potent check on their managerial prerogatives.

3. Regulation

$114 \quad$ REAGAN, supra note $112,145$.

115 Alfred D. Chandler, The Visible Hand: The MANAgerial ReVolution in AMERICAN BUSINESS 493 (1977).

116 Gerald Mayer, Union Membership Trends in the United States 22 (2004). See also Figure 2, infra note 146 and accompanying text.

117 KoTZ, supra note 12, 27; Susan Dynarski, With Solidarity Comes Income Equality, NY TIMES, July 8, 2018, Business, 4. 
In 1952 Fredrick Lewis Allen, the editor of Harper's magazine, suggested "the big and successful corporation" was "severely circumscribed by government." 118 During the heyday of managerial capitalism legislative measures and administrative missives that impinged upon public company executives most often targeted single industries. "Crossindustry" regulation applicable to corporations generally was not extensive throughout the 1950s and most of the 1960s. ${ }^{119}$ There were, however, exceptions. One was antitrust law, which Galbraith specifically cited when describing regulation as a source of countervailing power. ${ }^{120}$

The federal securities law regime introduced in the mid-1930s, which applied generally to corporations with publicly traded securities, was another exception to the prevailing pattern of single industry regulation. ${ }^{121}$ The Securities and Exchange Commission (SEC), which was charged with administering the regime, reputedly helped to keep "the corporate plutocracy under control through rules and regulations." ${ }^{22}$ Compliance with disclosure rules federal securities law imposed was similarly seen by contemporaries as "a most valuable discipline" 123 on the potentially wayward executive because "(h)e was no longer a secret deal-maker"124 and "a goldfish has got to be good."125

118 Fredrick Lewis Allen, The Big Change: AmEricA TransForms ItSElF 19001950239 (1952).

119 Louis Galambos \& Joseph Pratt, The Rise of the Corporate COMMONWEAlth: United States Business AND PUblic Policy IN THE 20 ${ }^{\mathrm{TH}}$ CENTURy 153 (1988).

$120 \quad$ Id.; supra notes 97-98 and related discussion.

121 Securities Act of 1933, 48 Stat. 74; Securities Exchange Act of 1934, 48 Stat. 881.

122 LIVINGSTON, supra note 52, 20.

123 MArtin Mayer, WALl Street: The InSIDE StORy OF AMERICAN FinANCE 243 (1959).

124 FinN, supra note 112, 44.

125 ALLEN, supra note 118, 240. 
As for single industry regulation, approximately one-quarter of the economy was directly affected during the 1950s and 1960s. ${ }^{126}$ In key sectors such as telecommunications, transport and utilities there was a system of "managed competition" with regulators enforcing standards and influencing pricing. ${ }^{127}$ When industry-specific regulation was in place, prior approval was often required to commence operations, markets were frequently segmented by product and geography and the need for profits was typically weighed explicitly against the public's interest in safe, fair and reliable service. ${ }^{128}$ Regulators, when exercising administrative discretion available to them, typically pursued policies that were designed to foster orderly growth along familiar, predictable lines. ${ }^{129}$ The emphasis on stability acted as a check on those running companies in the industries affected. Executives tended over time to become increasingly averse to risk, ${ }^{130}$ which would have discouraged freewheeling managerial gambles that could end up as scandals if things went awry.

Commercial banking provides an instructive, if somewhat extreme, example of how industry-specific regulation designed to foster orderliness discouraged managerial risk-taking during the middle decades of the $20^{\text {th }}$ century. By virtue of the Banking Act of $1933,{ }^{131}$ supplemented by the Bank Holding Company Act of $1956^{132}$ and other measures, commercial

126 WELLS, supra note 31, 43-44; Richard H.K. Vietor, Government Regulation of Business, in THE CAMBridge ECONOMIC History of THE United STATES, VOlume III: THE Twentieth Century 969, 986 (Stanley L. Engerman \& Robert E. Gallman, eds., 2000).

127 Rakesh Khurana, From Higher Aims to Hired Hands: THE Social TRANSFORMATION OF AMERICAN BUSINESS SCHOOLS AND THE UNFULFILLED PROMISE OF MANAGEMENT AS A PROFESSION 206 (2007).

128 Vietor, supra note 126, 987; ROBERT REICH, SUPERCAPITALISM: THE BATTLE FOR DEMOCRACY IN AN AgE OF Big Business 25 (2007).

129 GALAMBOS \& PRATT, supra note 119, 143.

$130 \quad$ Id.

131 Pub. L. No. 73-66, 48 Stat. 162.

132 Pub.L. No. 84-511, 70 Stat. 134. 
banking was one of the most heavily regulated sectors of the U.S. economy. ${ }^{133}$ Banks, for instance, were afforded little scope to carry out business activities unrelated to banking, meaning in this context taking deposits and making loans. ${ }^{134}$ At the same time, bank regulation precluded obvious potential competitors -- primarily investment banks subject to the strictures of the Glass Steagall Act of 1933 -- from engaging in core aspects of commercial banking. ${ }^{135}$ Federal and state law also ensured banking remained geographically fragmented, which served to protect banks from competition within their own industry. ${ }^{136}$

Franklin Moore, in a 1964 text on management, underscored the substantial impact regulation had on bank executives by characterizing them as "elevator operators, whose decisions are closely contained", as compared with executives in other industries who were like ship captains because "they can turn in any direction and go fast and slow."137 Dynamic, aggressive leadership was in turn conspicuous by its absence in the banking sector, with safety-first managers being in charge. ${ }^{138}$ The result was "boring" banking, characterized by stable profits and a very low failure rate by historical standards. ${ }^{139}$ Banking therefore illustrated, albeit in a somewhat extreme fashion, how industry-specific regulation could be a substantial constraint on managerial discretion during the heyday of managerial capitalism.

133 Ross N. Dickens \& George Philippatos, The Impact of Market Contestability on the Systematic Risk of U.S. Bank Stocks, 4 APP. FIN. ECON. 315, 315 (1994).

134 Helen A. Garten, Regulatory Growing Pains: A Perspective on Bank Regulation in a Deregulatory Age, 57 FordHAM L. REV. 501, 509-10 (1989); Michael Klausner, An Economic Analysis of Bank Regulatory Reform: The Financial Institutions Safety and Consumer Choice Act 1991, 69 WASH. U.L.Q. 695, 696, 698-703 (1991).

135 Garten, supra note 134, 516-17; Klausner, supra note 134, 695.

136 Cheffins, supra note 2, 20.

137 Franklin G. Moore, Management: Organization and Practice 31-32 (1964).

138 A. Dale Tussing, The Case for Bank Failure, 10 J.L. ECON. 129, 130-31 (1967); Anthony G. Chase, The Emerging Financial Conglomerate: Liberalization of the Bank Holding Company Act, 60 GEO. L.J. 1224, 1226 (1972).

139 Cheffins, supra note 2, 20-21. 
Regulation functioned as a constraint on public company executives not merely because of laws in place but also because of apprehension of further state intervention. Mid$20^{\text {th }}$ century executives feared they would assailed as greedy, domineering and grasping in the manner their forebears were during the Depression afflicted 1930s, with attendant regulatory consequences. ${ }^{140}$ When Fortune hailed in 1951 "the transformation of American capitalism" an important element was that "(o)ne of the most pressing concerns of almost every large company today is what people are going to think about it."141 Adolf Berle argued similarly in 1959 "managers of great corporations" had "a corporate conscience" due primarily to concerns about violating "the public consensus" where a breach would result in a "loss of prestige, public standing and popular esteem" and "the near-certainty of political intervention by the State." 142

The fact that it was not clear how public antipathy towards business might translate into government action compromised at least to some degree executive self-restraint based on public perceptions of business misconduct. ${ }^{143}$ Nevertheless, John Kennedy demonstrated in a 1962 showdown with the steel industry regarding pricing policy the leverage the government could exercise in the absence of formal legal authority. ${ }^{144}$ Kennedy was furious when leading

\footnotetext{
$140 \quad$ Broadside at Management, Bus. WK., Feb. 20, 1960, 129.

141 EDITORS (FORTUNE), supra note 15, 85.

142 BERLE, supra note 36 at 90-91, 114.

143 Mason, supra note 23, 8.

144 This summary is drawn from Joseph T. Salerno, From Kennedy's "New Economics"

to Nixon's "New Economic Policy": Monetary Inflation and the March of Economic Fascism in Reassessing the Presidency: The Rise of the Executive State and the DeCline of Freedom 587, 634-38 (John V. Denson, ed., 2001); B. MARK SMITh, TOWARd RATIONAL Exuberance: The Evolution of the Modern Stock Market 181-84 (2001).
} 
steel companies announced a steel price increase shortly after a potentially debilitating steel industry strike had been narrowly averted without a wage hike. With Kennedy vilifying publicly the steel companies that had raised prices, administration officials announced plans to launch an investigation into price-fixing in the steel industry and to shift defense purchases to companies not planning to charge customers more. The steel companies which had announced they intended to increase prices promptly retreated. Berle, in a New York Times op-ed, maintained that Kennedy's challenge to the steel industry demonstrated the power of big business operated subject to "an unwritten "social contract"” under which the government could "intervene when economic power in private hands threatens the economic community of the United States." ${ }^{455}$ Even discounting Berle's rhetorical flourishes, the steel industry incident indicated vividly that in the 1950s and 1960s the mere threat of governmental meddling was part of the countervailing power of the state that constrained managerial discretion.

\section{COUNTERVAILING POWER RECONFIGURED}

Unions and regulation, as sources of countervailing power that functioned as meaningful external constraints on managerial discretion during the 1950s and 1960s, help to explain why managerial propriety was very much the norm despite the weakness of internal accountability mechanisms. The potency of countervailing power mechanisms would evolve in the decades that followed. With unions, the trend line was a consistent one: organized labor weakened steadily as a check on public company executives. As for state intervention (or the threat thereof), a deregulatory trend that began in the late 1970s and ran until the 2000s served to enhance managerial discretion. This period was preceded and followed, however, by marked growth in regulatory activity. Finally, while competitive pressure from

145 Adolf A. Berle, Unwritten Constitution for Our Economy, N.Y. TIMES, April 29, 1962, 208. 
rivals was treated as something of an afterthought during the ostensibly oligopolistic heyday of managerial capitalism, it would increase in importance as a source of managerial discipline thereafter.

\section{A. Unions}

Basic data indicate clearly that the power of unions declined markedly following the middle decades of the $20^{\text {th }}$ century. Union density, for instance, fell dramatically (Figure 2). The number of major strikes dropped even more sharply (Figure 3).

Figure 2: Union Membership as a Percentage of Wage and Salary Workers, 1950-2010

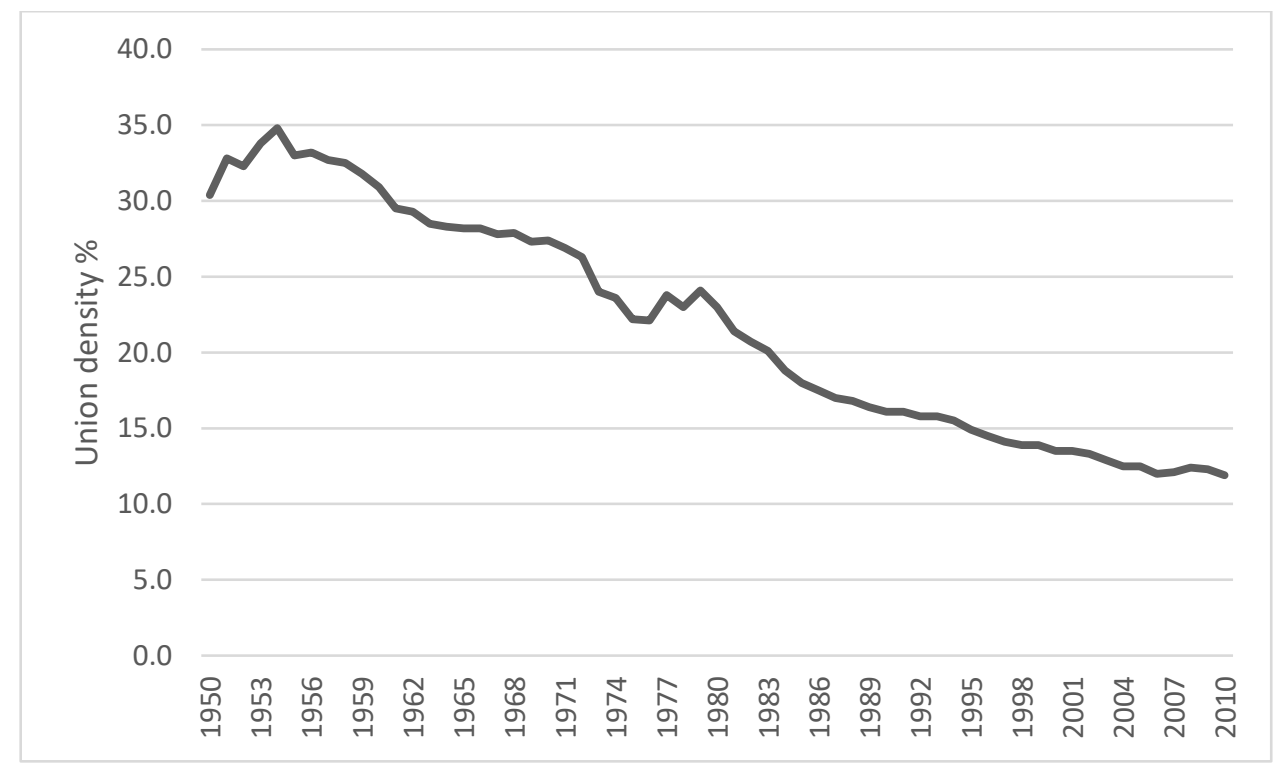

Sources: Mayer (2004), 1950-72; Unionstats.com, 1973-2010 146

Figure 3: Work Stoppages Involving 1000 or More Workers, 1950-2010

146 MAYER, supra note 116 at 22; Unionstats.com, Union Membership and Coverage Database from the CPS, available at http://unionstats.gsu.edu/ (accessed April 26, 2018). 


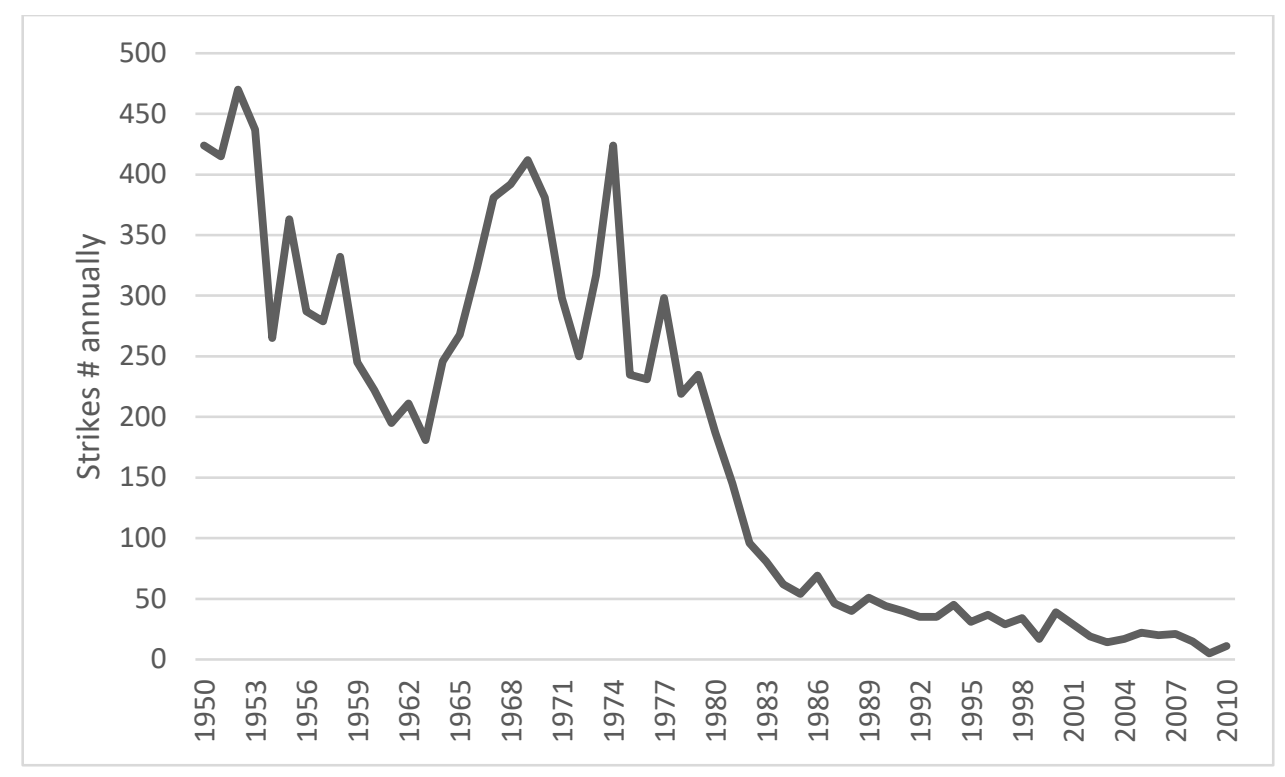

Source: Bureau of Labor ${ }^{147}$

Views expressed by contemporaries confirm the inexorable decline of unions as a constraint on managerial discretion. Lawyers Ira Millstein and Salem Katsh, in a 1981 book canvassing limits on corporate power, argued that the process of collective bargaining sharply diminished corporate flexibility and said "(t)he power of unions to constrain corporate behavior is widely acknowledged."148 Others were suggesting, however, by the end of the 1970s that unions were "in disarray", 149 "embattled" and "threatened...by a panoply of woes."150 As for the 1980s the Washington Post said in 1989 it "has been a decade of despair for many in the labor movement" and that "(o)rganized labor is in trouble as it marks the end of one of its worst decades in postwar history." 151 With the 1990s, Fortune labelled

147 Bureau of Labor Statistics, Work Stoppages Involving 1,000 or More Workers, 19472017, available at https://www.bls.gov/news.release/wkstp.t01.htm (accessed April 26, 2018). 148 IRA Millstein \& SAlem KATSH, The Limits OF CORPORATE POWER: EXISTING CONSTRAINTS ON THE EXERCISE OF CORPORATE DISCRETION 151, 236 (1981).

149 Stewart Fleming, The Businessman Returns to Favor in Washington, FIN. TIMES, Oct. 24, 1978, 1.

150 Embattled Unions Strike Back at Management, Bus. WK., Dec. 4, 1978, 54.

151 Frank Swoboda, Organized Labor Toughens its Stance, WASH. Post, Sept. 3, 1989, H1. 
American unions as "hopeless losers" in 1994 and the New York Times said in 1996 that "labor faces an uphill fight" and was "on the defensive almost everywhere."152

By the 2000s fewer than one out of six workers were members of a union. ${ }^{153}$ A 2006 text on the corporation indicated that even when a workforce was unionized, "( $t$ )oday unions are not a threat to corporations provided management treats workers with fairness and respect." ${ }^{154}$ The inexorable decline of organized labor meant that only in exceptional situations would unions operate as a meaningful constraint for public company executives.

\section{B. Regulation}

The 1970s have been described as an era when "(g)overnment regulation...expanded" in various ways that placed "limits on managers" ability to run their firms." 155 This indeed was true for most of the decade. Between 1967 and 1977 Congress enacted "nearly 100 substantial pieces of legislation affecting the conduct of business."156 There was also a shift in emphasis away from industry-specific regulation in favor of "social" regulation that crossed industry lines and defined in relation to a particular facet of economic activity the applicable ground rules. ${ }^{157}$ Regulatory agencies created to administer the statutory measures included the Equal Employment Opportunity Commission, the National Highway Traffic

152 Daniel Seligman, Why Labor Keeps Losing, ForTune, July 11, 1994, 178; Peter T. Kilborn, Organized Labor's Hope for a Comeback, N.Y. Times, March 8, 1996, A22.

153 Unionstats.com, supra note 146.

154 Wesley B. Truitt, The Corporation 236 (2006).

155 MIZRUCHI, supra note 96, 204.

156 Robert Bleiberg, Shareholder Constituency? The Liabilities Probably Outweigh the Assets, BARRON's, Aug. 29, 1977, 57.

157 MizRUCHI, supra note 96, 162-63; EICHAR, supra note 110, 227, 247-48; James Q. Wilson, The Corporation as a Political Actor in AMERICAN CORPORATION, supra note 96, 413, 417-18. 
Safety Administration, the Occupational Safety and Health Administration, the Consumer Product Safety Commission, and the Environmental Protection Agency. ${ }^{158}$

In the late 1970s, a continuation of the trend favoring increased regulation of business seemed a good bet, given Congress' recent legislative proclivity, given that control of Congress rested in the hands of the usually left-leaning Democrats and given the election of Democrat Jimmy Carter as president in $1976 .{ }^{159}$ In fact, the tide was turning. The Watergate political scandal that prompted Richard Nixon's 1974 resignation as President, the collapse of U.S.-backed South Vietnam in 1975, chronic federal budget deficits and repeated failed efforts to bring inflation under control fostered what Newsweek characterized in 1979 as "a growing sense that the country's institutions and leaders were no longer up to managing problems that were simply too complex to grasp." 160 Polling data indicated that distrust of government intervention grew from 32 percent in 1964 to 50 percent in 1972 and 67 percent in $1980 . .^{161}$

Amidst substantial erosion of support for governmental action, the legislative juggernaut launched in the late 1960s stalled. ${ }^{162}$ The shifting political tides of the late 1970 s would not merely call a halt to increased regulation, however. Instead, growing antipathy toward government would also act as a catalyst for a deregulation movement that would

\footnotetext{
$158 \quad$ Vietor, supra note 126, 988; MANSEL G. BLACKFORD \& K. AUSTIN KERR, BUSINESS ENTERPRISE IN AMERICAN HISTORY 405-9 ( $2^{\text {nd }}$ ed., 1990); ARCHIE B. CARROLL ET AL., CORPORATE RESPONSIBILITY: THE AMERICAN EXPERIENCE 234 (2012).

159 EICHAR, supra note 110, 260.

160 Larry Martz, The Limits of Power, NewsweEk, Nov. 19, 1979, 86. See also Vietor, supra note 126, 996; BENJAMIN C. WATERHOUSE, THE LAND OF ENTERPRISE: A BUSINESS HISTORY OF THE UNITED STATES 223 (2017).

161 Seymour Martin LiPSET \& William Schneider, The CONFIDENCE GaP: Business, LABOR, AND GOVERNMENT IN THE PUBLIC MIND 33 (1983).

162 Benjamin Waterhouse, Corporate Mobilization Against Liberal Reform in WHAT'S GoOd FOR Business: Business AND AMERICAN Politics Since World WAR II 233, 235 (Kim Phillips-Fein \& Julian Zelizer, eds., 2012).
} 
expand considerably managerial discretion as the $20^{\text {th }}$ century drew to a close. Deregulation is often treated as a core element of Ronald Reagan's presidential legacy but the push to deregulate was well underway by the time he took office in $1981 .{ }^{163}$ Deregulatory moves carried out under the Carter administration included wiping away entry, route and rate restrictions in the trucking industry, liberalizing rate setting and route selection for airlines and railways, loosening controls on natural gas prices and relaxing interest rate ceilings on bank accounts. ${ }^{164}$

Ronald Reagan was elected to the presidency in 1980 and a cornerstone of his administration was its "four square commitment to deregulation." 165 Legislative change was in fact fairly modest. The Garn-St. Germain Depository Institutions Act of 1982, which further eased restrictions on interest rates payable on bank accounts, ${ }^{166}$ and the Cable Television Act of $1984^{167}$ were the only major industry-specific deregulatory measures promulgated under Reagan. ${ }^{168}$ Reagan did achieve, however, meaningful deregulatory results by appointing agency and department heads who shared his bias against governmental burdens and prioritized lowering compliance costs. ${ }^{169}$ Newsweek said of the administrative tone in 1984 "business seems encouraged by a change in the regulatory climate. It's not that the absolute level of regulation is expected to decline, but that the rule making has become

163 ReICH, supra note 128, 65; JOHN STEELE GORDON, AN EMPIRE OF WEALTH: The EPIC HisTORY OF AMERICAN ECONOMIC POWER 392-93 (2004).

164 Vietor, supra note 126, 999-1006.

165 SKEEL, supra note 38, 120.

166 Pub. L. No. 97-320, 96 Stat. 14 (1982). For a summary of the changes, see Joseph Jude Norton, The 1982 Banking Act and the Deregulation Scheme, 38 BUS. LAWYER 1627, 1633-34 (1983).

167 Pub. L. No. 98-549, 98 Stat. 2779 (1984).

168 Vietor, supra note 126, 1009.

169 WATERHOUSE, supra note 160, 195. 
less capricious. Executives no longer worry, for example, that a single change in the federal air-quality standards might render hundreds of millions of dollars of investment obsolete."170

Robert Reich, a Harvard academic who would serve in the Clinton administration in the 1990s, claimed in 1985 that due to deregulation "(n)ot since the '20s has big business been so unconstrained."171 Reich invoked Galbraith to emphasize his point. Reich said Galbraith had written in the 1950s "reassuringly of the 'countervailing power' in the American system" but cited cutbacks to regulation when telling readers that "in the America of the eighties, these counterweights have been all but removed." ${ }^{172}$ While this likely overstates the freedom on offer to public companies and their executives, deregulation occurring during the late 1970s and the 1980s did afford executives in industries affected substantial discretion previously unavailable. The unravelling of constraints on pricing, distribution patterns and product innovation created new opportunities to capture market share and generate profits while simultaneously introducing substantial downside risk for formerly cossetted incumbents by removing regulatory "safety nets". ${ }^{173}$

The expansion of managerial discretion deregulation precipitated continued when Democrat Bill Clinton was elected president in 1992. Clinton indeed proclaimed in his 1996 State of the Union address "the era of big government is over." ${ }^{174}$ Deregulation was being

170 Harry Anderson, A Surprising Surge In Productivity, NEWSWEEK, Feb. 6, 1984, 62.

171 Robert B. Reich, The Executive's New Clothes, New Republic, May 13, 1985, 23. $172 I d$

173 SKEEL, supra note 38, 159-60; Stacey Kole and Kenneth Lehn, Deregulation, the Evolution of Corporate Governance Structure, and Survival, 87 AMER. ECON. REV. 421, 425 (1997).

174 Alison Mitchell, Clinton Offers Challenge to the Nation, Declaring "Era of Big Government is Over", N.Y. TIMES, Jan. 24, 1996, A1. 
analogized to a "tidal force" as the 1990 s drew to a close. ${ }^{175}$ Some regard the 1990 s as "the decade of deregulation." 176

Throughout much of the 1990s, deregulatory legislation was passed at an energetic pace matching that set in the late 1970s. ${ }^{177}$ The Energy Policy Act of 1992 dismantled restrictions on sales of power between utility companies so as to foster competition in a sector local monopolies traditionally dominated. ${ }^{178}$ The Riegle-Neal Interstate Banking and Branching Efficiency Act of 1994 eliminated most regulatory obstacles to interstate bank acquisitions and put in place a national framework for banks to operate across state lines, culminating a trend in favor of facilitating multi-state banking various states had begun in the late 1970 s. ${ }^{179}$

In 1995, the Interstate Commerce Commission, which had regulated interstate surface transportation since 1887, was shut down but President Clinton still chided Congress for failing to back bolder steps to deregulate transportation industries. ${ }^{180}$ The Telecommunications Act of 1996 permitted long distance and local telephone companies, such as "Baby Bells" created when erstwhile telephone monopolist AT\&T was broken up in

175 ChARLES DERBER, CORPORATION NATION: HOW CORPORATIONS ARE TAKING OVER OuR Lives AND What We CAN DO ABOUt IT 149 (1998).

176 STYHRE, supra note 11, 146, 150; CHARLES R. GEISST, UNDUE INFLUENCE: How THE WALl StREet Elite PUTS the FinANCIAL SYSTEM AT RISK 241 (2005).

177 Joseph D. Kearney \& Thomas W. Merrill, The Great Transformation of Regulated Industries Law, 98 COLUM. L. REV. 1323, 1381-82 (1998).

178 Pub. L. No. 102-486, 106 Stat. 2776 (1992); ChARLES R. GEISST, DEALS OF THE Century: Wall Street, Mergers, ANd the Making of Modern America 243 (2001).

179 Pub. L. No. 103-328, 108 Stat. 2338 (1994); James R. Barth, Tong Li \& Wenling Lu, Bank Regulation in the United States, 56 CESFIO ECON. STUD. 112, 126-27 (2010).

180 ICC Termination Act of 1995, Pub.L. 104-88, 109 Stat.803; William J. Clinton, Statement on Signing the ICC Termination Act of 1995 (December 29, 1995), available at http://www.presidency.ucsb.edu/ws/?pid=52436 (accessed Feb. 14, 2018). 
1982 as a result of antitrust proceedings, to compete against each other. ${ }^{181}$ The legislation also relaxed restrictions on ownership of television and radio stations and allowed cable communication companies and telephone carriers to enter each other's markets. ${ }^{182}$ Finally, the 1999 Gramm-Leach-Bliley Act formalized the dismantling of barriers between commercial and investment banking the Glass Steagall Act of 1933 had established and explicitly authorized the creation of full-service financial holding companies. ${ }^{183}$

The state was not in full-scale retreat in the 1990s. Sociologist Charles Derber maintained in 1998 “(g)overnment remains the most important potential countervailing threat to corporate power." 184 While Reagan appointees to federal agencies typically shared his bias against governmental burdens, Clinton chose personnel intellectually committed to the underlying regulatory mission of the agencies they served and the legislation they were administering. ${ }^{185}$ Federal officials also fostered the development of compliance systems within corporations by issuing guidelines for prosecution and sentencing of criminal violations that contemplated increased penalties for corporate wrongdoing but embraced mitigation where an effective compliance program was in place. ${ }^{186}$ Nevertheless, due to deregulation 1990s public company executives often had when exercising managerial discretion considerably greater room to move than their managerial capitalism era peers.

181 Pub. L. No. 104-104, 110 Stat. 56 (1996); Tim Wu, The Master Switch: The Rise AND FALL OF INFORMATION EMPIRES 243-44 (2010).

182 Hanglong Fu, Yi Mou \& David Atkin, The Impact of the Telecommunications Act of 1996 in the Broadband Age, 8 AdVANCES COMMUNICATIONS \& MEDiA Res. 117, 122-23 (2011).

183 Pub.L. 106-102, 113 Stat. 1338 (1999); Arthur E. Wilmarth, The Transformation of the U.S. Financial Services Industry, 1975-2000: Competition, Consolidation, and Increased Risks [2002] U. ILL. L. REV. 217, 319-20.

184 DERBER, supra note $175,65$.

$185 \quad$ Supra note 169 and related discussion; EICHAR, supra note 110, 292.

186 Griffith, supra note 4, 2084-87. 
As the 2000s got underway, it appeared the deregulation trend would continue. George W. Bush, in his successful 2000 presidential election campaign, sought to woo business community support by promising to continue to scale back federal interference. ${ }^{187}$ In fact, the deregulatory momentum reversed in the 2000s, leading the New York Times in 2005 to harken back to Bill Clinton's 1996 proclamation on the perilous state of big government and declare "( $\mathrm{t}$ )he era of big government being over is over." 188

Events partially dictated the retreat from deregulation. The terrorist attacks occurring on September 11, 2001 prompted Congress to create the Transportation Security Administration, the first big new federal bureaucracy set up in more than a quarter century. ${ }^{189}$ There were, however, broader pro-regulatory trends at work, evidenced by an inflationadjusted 45 percent growth in spending on economic regulatory agencies during the 2000 s combined with a 12 percent increase in staffing levels. ${ }^{190}$ This expansion in governmental activity chimed with public attitudes. According to a 2008 poll Americans wanted government to "do more to solve problems" by a 53 percent-to- 42 percent margin whereas a dozen years previously respondents opposed additional government intervention by a 2-to-1 margin. ${ }^{191}$

The trend in favor of regulation continued, and accelerated, when Barack Obama became president in 2009. A total of 486 regulations expected to have an economic impact

187 Jeanne Cummings, Jacob M. Schlesinger \& Michael Schroeder, Bush Crackdown On Business Fraud Signals New Era, Wall St. J., July 10, 2002, A1.

188 Sheryl Gay Stolberg, The Revolution That Wasn't, N.Y. TimES, Feb. 12, 2005, D1.

189 Alan Murray, Revolt in The BoARdroOM: The New Rules of POWER IN CORPORATE AMERICA 31 (2007).

190 Veronique de Rugy \& Melinda Warren, Regulatory AgEncy SPENDing

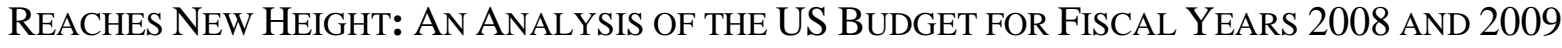
6, 9 (2008).

191 Bob Davis, Damian Paletta \& Rebecca Smith, Unraveling Reagan, WALL ST. J., July 25, 2008, A1. 
of $\$ 100$ million or more were promulgated during the eight years Obama was president, as compared with 358 under Bush. ${ }^{192}$ Moreover, Obama's "regulations were, on the whole, bigger and bolder than what had come before." ${ }^{193}$ The New York Times, in a 2016 retrospective series on the Obama presidency, even labelled him "the Regulator in Chief."194

The scaling up of regulation during the Obama administration impinged upon managerial discretion in the corporate sector. Analysis of disclosures by publicly traded companies indicated regulatory risk jumped nearly 80 percent across industries between 2010 and 2015. ${ }^{195}$ Corporate executives were well aware increased governmental oversight was circumscribing options. Fortune indicated in a 2016 article on regulatory "red tape" that "right now the hue and cry from the business community is louder than at just about any time in recent memory." 196 The Business Roundtable, an association of chief executives of leading public companies, joined those voicing concern. The introduction to a set of corporate governance principles the Business Roundtable issued in 2016 noted " $(\mathrm{t}) \mathrm{he}$ increased regulatory burdens imposed on public companies in recent years have added to the costs and complexity of overseeing and managing a corporation's business and bring new challenges from operational, regulatory and compliance perspectives.”197

192 Derived from data available at George Washington Regulatory Studies Center, Reg Stats - Economically Significant Regulations Issued Each Year, available at https://regulatorystudies.columbian.gwu.edu/reg-stats (accessed June 1, 2018).

193 Grudges and Kludges, ECONOMIST, March 4, 2017, 30.

194 In the series, the label was used to tag an online version of a print story that did not include the phrase. See https://www.nytimes.com/2016/08/14/us/politics/obama-era-legacyregulation.html (accessed May 5, 2018).

195 Clark S. Judge, The Rust Belt Is Right To Blame Obama, WALl ST. J., Dec. 19, 2016, A21 (discussing research by VogelHood Group).

196 Brian O'Keefe, The Red Tape Conundrum, Fortune, Nov. 1, 2016, 76.

197 Business Roundtable, PRINCIPLES OF CORPORATE GOVERNANCE 1 (2016). 
New regulations the Obama administration generated addressed a wide range of issues, including health care, the environment and workplace safety. ${ }^{198}$ Due, however, to the Dodd-Frank Act of $2010,{ }^{199}$ the primary federal legislative response to the 2008 financial crisis, ${ }^{200}$ banking was the industry where managerial discretion was most substantially compromised. Even with deregulation occurring in the 1980s and 1990s banking was one of the more heavily regulated industries in America. ${ }^{201}$ Still, bank executives were operating with a freedom their managerial capitalism counterparts would have struggled to contemplate. The Economist said of U.S. banks in 2000 that "bank managers, long thought of as sober sorts, have, in effect, tried all sorts of ways to turn banking into a high-growth business. They have bought other banks, slashed costs, gone into pastures new and taken more risk, in many different guises.",202

Matters were much different after Dodd-Frank. Regulators, fortified by their DoddFrank mandate, stepped up considerably their scrutiny of banks, a process characterized by the Wall Street Journal in 2017 as "politicians and bureaucrats join(ing) in a remorseless and determined effort to tighten regulation."203 Bankers were well aware of the pattern. The CEO of financial services powerhouse Morgan Stanley agreed when his predecessor

198 How the President Came to Embrace Executive Power, N.Y. TIMES, Aug. 14, 2016, A1.

199 Dodd-Frank Wall Street Reform and Consumer Protection Act of 2010 (hereinafter Dodd-Frank Act), Pub. L. 111-203, 124 Stat. 1376.

200 Charles W. Murdock, The Dodd-Frank Wall Street Reform and Consumer Protection Act: What Caused the Financial Crisis and Will Dodd-Frank Prevent Future Crises, 64 S.M.U. L. REV. 1243, 1246 (2011).

201 John D. “Jay” Cornet, Bank Governance: An Independent Director's Perspective, 7 N.C. BANKING INST. 1, 2 (2003).

202 The Bigger They Are, ECONOMIST, Oct. 28, 2000, 115.

203 Tim Congdon \& Steve H. Henke, More Bank Capital Could Kill the Economy, WALL ST. J., March 14, 2017, A17. 
suggested in 2013 "(y)our No. 1 client is the government."204 Analogies in turn were regularly drawn between post-financial crisis banks and cautiously run public utilities so as to underscore the level of risk aversion. ${ }^{205}$ Banking thus exemplified how regulation had emerged since the early 2000s as an increasingly potent constraint on managerial discretion.

\section{Competition}

Due to oligopolistic market conditions assumed to prevail widely during the heyday of managerial capitalism in the 1950s and 1960s pressure from market rivals was treated as a secondary element in the world of countervailing power. ${ }^{206}$ Perceptions of competition as an external accountability mechanism would change considerably in the ensuing decades. There was a foreign dimension involved. As the 1970s drew to a close rivals from abroad were outflanking American corporations with sufficient regularity to prompt debate in the U.S. on the topic of national competitiveness. ${ }^{207}$

Unions were among those feeling the pinch as foreign competition ramped up. Market power large corporations had in the 1950s and 1960s created "slack" that left room for concessions to unions. ${ }^{208}$ Employers pressured by foreign rivals in the 1970 s realized they could no longer simply pass increased labor costs along to consumers and dug their

204 Aaron Lucchetti \& Julie Steinberg, Life on Wall Street Grows Less Risky, WALL ST. J., Sept. 10, 2013, A1.

205 Kirsten Grind \& Emily Glazer, Inside Enforcers Shake Up Bank Culture, WaLl ST. J., May 31, 2016, A1; Patrick Jenkins, Too Dull to Fail?, Fin. TIMES, Sept. 7, 2016, 9; DAVID M. SMick, The Great Equalizer: How Main StREet Capitalism CAN CREATE AN ECONOMY FOR EVERYONE 87 (2017).

206 Supra notes 108-10 and related discussion.

207 William E. Kovacic, The Antitrust Paradox Revisited: Robert Bork and the Transformation of Modern Antitrust Policy, 36 WAYNE L. REV. 1413, 1443 (1990). 208 REICH, supra note $128,81$. 
heels in. ${ }^{209}$ Organized labor in turn found itself under an onus to accommodate management, at least to some degree. The United Automobile Workers, for example, acknowledged in 1979 that it agreed "to a cheap contract" with Chrysler because the automaker, put on the back foot by foreign competitors, was "threatened with bankruptcy." ${ }^{210}$ Correspondingly, the development of pressure from rivals into a more potent source of countervailing power fostered a simultaneous trend in the opposite direction with unions.

Moving into the 1980 s, the overseas challenge continued to preoccupy executives running domestic firms. Business Week said in 1987 there was "a new, hard nosed approach to business in the U.S." with "the leanest and meanest" offering "America's best shot at turning back a tide of foreign competition."211 The growth in competitive pressure in the 1980s also had a substantial domestic component. Entrepreneurial values were being lauded in a way that was novel for the post-World War II era. ${ }^{212}$ This provided a congenial setting for the growth of companies that could and would challenge powerful incumbents, such as Harvard drop-out Bill Gates and Microsoft stealing a march on information technology behemoth IBM with respect to the development of computer operating systems. ${ }^{213}$ Deregulation also was a catalyst for the challenging of heretofore dominant firms, at least in the industries specifically targeted. ${ }^{214}$ A Business Week columnist said in 1987 the policy had

209 KoTZ, supra note 12, 80-81; Unions Eye Some New Directions, CHRIS. SCI. Monitor, Sept. 27, 1979, 10.

210 Harry Bernstein, Unionists on Boards Not a New Concept, L.A. TIMES, Oct. 27, 1979, C1.

211 America's Leanest and Meanest, Bus. WK., October 5, 1987, 78.

212 See, for example, Daniel Burstein, Big Business v. the Entrepreneur, L.A. TIMES, Dec. 5, 1986, B5.

213 Victor R. Zonana, Cocky Microsoft Set to Challenge Software Rivals on Their Own Turf, L.A. Times, Aug. 23, 1987, D1.

214 JOHN P. KOTTER, THE LEADERSHIP FACTOR 5-6 (1988). 
"exposed managerial complacency and inefficient practices caused by years of shelter from market forces." 215

The disciplinary effect of challenges by rivals grew further in the 1990s. Joel Klein, head of the Justice Department's Antitrust Division, claimed in 1998 that “our economy is more competitive today than it has been in a long, long time.”216 Management theorist Gary Hamel captured evocatively fears competitors were eliciting in the corporate ranks, saying in 1999 “(f)ace it: Out there in some garage, an entrepreneur is forging a bullet with your company's name on it. Once that bullet leaves the barrel, you won't be able to dodge it."217

The tribulations of various well-known corporations provided anecdotal evidence confirming conjectures about increased competitive pressure. "All around us we hear the thuds of dinosaur organizations hitting the decks" management professor Thomas Vollmann declared in 1996. ${ }^{218}$ "The most visible hulks in Dinosaurland" included erstwhile corporate icons such as General Motors, IBM, Sears and Kodak. ${ }^{219}$ Awareness of competitive pressure in turn affected the managerial mind-set. Marina von Neumann Whitman, a business school professor and former General Motors executive, argued in 1999 that for executives “(i)ntense competitive pressures" were diluting "the concentration of managerial power" and had "reduced managerial complacency."220

215 Judith H. Dobrzynski, Why Nothing Seem to Make a Dent in Dealmaking, Bus. WK., July 20, 1987, 75 .

216 Too Much of a Good Thing, ECONOMIST, March 26, 2016, 23.

217 Gary Hamel, Bringing Silicon Valley Inside, HARV. Bus. REV., Sept./Oct. 1999, 70,

72.

218 Thomas E. Vollmann, AchiEving Market Dominance Through Radical Change 11 (1996).

219 Carol J. Loomis \& Joshua Mendes, Dinosaurs, Fortune, May 3, 1993, 36.

220 Marina v. N. Whitman, New World, New Rules: The Changing Role of the AMERICAN CORPORATION 30, 43, 199 (1998). 
The rise of the internet in the 1990s was a significant reason why public company executives felt pressure from rivals was intensifying as the $20^{\text {th }}$ century drew to a close. Business Week picked up on the theme in a 1999 cover story entitled "Internet Anxiety":

"Simply put, there's a revolution under way, and mastering the Net has moved front and center on Corporate America's agenda....Throughout Corporate America, executives are suddenly waking to the realization that those who don't move fast to get in on the game risk having their lunch eaten by tiny rivals who may have barely existed just a few years ago." 221

Those in charge of corporations dominant within a market sector were apprehensive of the internet primarily because it was suddenly much easier for buyers and sellers to find each other and for customers to engage in comparison shopping for the best deal. ${ }^{222}$

Competitors remained a headache for public company management during the 2000s. With respect to foreign rivals, China's growing strength was drawing considerable attention. ${ }^{223}$ For instance, a 2006 study of public company executives warned "the current global economy has little patience for companies that can't 'hack it"” and that "(t)he Asian tigers are back, fiercer than before, now that China is among them."224

On the domestic front, the ongoing growth of the internet continued to bolster firms seeking to challenge dominant incumbents. A 2011 study of the evolution of management theory indicated, for instance, "(t)he internet has made it easier for Davids to take on

$221 \quad$ Nanette Byrnes, Internet Anxieties, Bus. WK., June 28, 1999, 79.

222 GORDON, supra note 163, 412; Robert Kuttner, Bill Gates, Robber Baron, Bus. WK., Jan. 19, 1998, 20.

223 Keith Bradsher, Like Japan in the 1980s, China Poses Big Economic Challenge, N.Y. TIMES, March 2, 2004, A1.

224 LeONARD R. SAYles \& Cynthia J. SMith, The Rise of the Rogue EXeCUtive: How Good COMPANiEs Go BAD AND How to STOP THE Destruction 27, 46 (2006). 
Goliaths." 225 This, in turn, had "forced established Goliaths to improve their game."226 Robert Reich even suggested in 2007 that "supercapitalism" had taken hold in the U.S., characterized by “ever more intensifying competition among businessmen."227 Reich's nomenclature may have been somewhat hyperbolic but competition from rivals clearly was a substantially more robust managerial constraint than was the case in Galbraith's era.

\section{INTERNAL ACCOUNTABILITY MECHANISMS FORTIFIED}

The operation of unions and regulation as sources of countervailing power help to explain why the 1950s and 1960s were an era of managerial propriety despite neither boards nor shareholders constraining managerial discretion substantially. As Part III indicated, both unions and regulation receded in importance as accountability mechanisms as the $20^{\text {th }}$ century drew to a close. Given the separation of ownership and control that had become and would remain a characteristic of public companies, ${ }^{228}$ there correspondingly was potentially wide scope for managerial waywardness. Intensifying competition between firms was a partial counterbalance.

A strengthening of internal accountability mechanisms also helped to keep late $20^{\text {th }}$ century public company executives in check. The process began in earnest in the 1970s with boards, with changes often being discussed in terms of improving corporate governance.

Stockholders were slower off the mark but the continuation of a shift in favor of institutional ownership at the expense of retail investors ultimately served to bolster shareholder monitoring capabilities. A by-product would be that a managerial shift of priorities in favor

\footnotetext{
225 Adrian WoOldridge, Masters of MANAGEMENT 148 (2011).

$226 \quad I d$.

227 REICH, supra note 128, $\mathrm{x}$.

228 Supra notes 22-25 and related discussion; Cheffins and Bank, supra note 24, 464-66, 473-74 (Appendix 6).
} 
of the promotion of shareholder value a wave of hostile takeovers in the 1980s prompted would be sustained when the takeover activity abated. Neither boards nor shareholders, however, functioned optimally as internal accountability mechanisms, as illustrated by highprofile examples of managerial malfeasance in the early 2000 s.

\section{A. Boards of Directors}

The 1970s opened with a corporate collapse that illustrated starkly the weakness of boards as an accountability mechanism. Penn Central was the product of a merger between the Pennsylvania Railroad and the New York Central railway, with discussions of consolidation extending back to the late 1950s climaxing in 1968 when the U.S. Supreme Court gave the green light. ${ }^{229}$ Just two years later Penn Central was in crisis. Bankruptcy proceedings involving Penn Central's railway assets would end up being the largest in history to that point. ${ }^{230}$ Prior to the collapse, Penn Central was a "management mess", with a chairman of the board who was more interested in real estate holdings acquired as part of a diversification plan than in railways, a chief executive officer who was ignored and a railway network plagued by mis-routings and other foul ups. ${ }^{231}$ The Penn Central board was asleep at the switch throughout. ${ }^{232}$ One director admitted that the board was little more than a "rubber stamp" and provided a "horrible example". 233

Revelations of corporate impropriety would extend beyond Penn Central before long. The Watergate Special Prosecutor's Office successfully prosecuted nearly 20 companies for violating campaign finance laws in relation to the 1972 presidential election, meaning the

\footnotetext{
229 Toward the 21st Century Ltd., TIME, Jan. 26, 1968, 82.

230 Paul Blustein, The Reincarnation of Penn Central”, Forbes, May 1, 1977, 50.

231 Robert Sobel, When Giants StUMble 208 (1999).

232 Joseph R. Daughen \& Peter Binzen, The Wreck of the Penn Central 9-10, 17 (1971).

233 To Resign or Challenge, ForBes, May 15, 1976, 104.
} 
Watergate scandal shook public confidence in the business community as well as politicians. ${ }^{234}$ During the mid-1970s dozens of U.S. public corporations revealed under a voluntary disclosure scheme the SEC had established that they had made illegal or questionable foreign payments during the first half of the decade. ${ }^{235}$ In many of these companies one or more members of senior management knew of or approved the illicit practices but the outside directors were uniformly ignorant of what was going on. ${ }^{236}$ This represented, according to the SEC, "frustration of our system of corporate accountability."237

As concerns about managerial waywardness increased during the 1970s the term "corporate governance" moved into the limelight as it was deployed for the first time with regularity in newspapers, academic journals and other publications. ${ }^{238}$ This was accompanied by changes in the boardroom oriented around fortifying the board's role in monitoring management. ${ }^{239}$ For instance, at the SEC's urging, the New York Stock Exchange amended its listing rules in 1977 to make the establishment of an audit committee comprised of outside directors a condition of listing. ${ }^{240}$

Before the 1970s drew to a close public company executives were themselves acknowledging that it was sound practice for outside directors to be well-represented on

234 LeONARd Silk AND DAVId Vogel, ETHICS AND Profits: The CRISIS OF CONFIDENCE IN AMERICAN BUSINESS 17 (1976).

235 Prominent examples are summarized in CORRUPTION IN BUSINESS 150-55 (Lester A. Sobel, ed., 1977).

236 Joel Seligman, The Transformation of Wall Street: A History of the SECURITIES AND EXCHANGE COMMISSION AND MODERN CORPORATE FinANCE 537 (1982). $237 \quad I d$. at 542.

238 Cheffins, supra note 13, 727-28.

239 Jeffrey N. Gordon, The Rise of Independent Directors in the United States, 19502005: Of Shareholder Value and Stock Market Prices, 59 STANFORD L. REV. 1465, 1518 (2007). 
boards and for certain key board tasks to be delegated to committees outside directors dominated. ${ }^{241}$ Companies were in turn reconfiguring their boards voluntarily to foster monitoring of management. Among 270 major industrial, transportation and distribution companies the proportion of board seats held by full-time executives dropped from 54 percent in 1970 to 43 percent in $1980 .^{242}$

Voluntary change was prevalent as well with board committees. According to Conference Board data relating to large industrial companies the proportion with an audit committee increased from 19 percent in 1967 and 45 percent in 1972 to 93 percent just prior to the NYSE changing its listing rules. ${ }^{243}$ The proportion which had set up compensation committees to deal with the delicate issue of executive pay rose from 57 percent to 72 percent and to 90 percent over the same period. ${ }^{244}$ While only 7 percent of public companies in 1972 had a nomination committee in place to select candidates for directorships, this figure increased to 29 percent in 1979, including 38 percent of companies listed on the NYSE. ${ }^{245}$

With respect to the reconfiguring of boards, in the 1980 s "the 1970 s

trend...continued, although more slowly."246 By the early 1990s it seemed boards had come into their own as a monitoring mechanism. Dismissals of CEOs at prominent companies such as Goodyear, Westinghouse, American Express, General Motors, IBM, and Kodak

241 Business Roundtable, The Role and Composition of Directors of the Large Publicly Owned Corporation, 33 Bus. LAw. 2083, 2107-10 (1978).

242 Barry D. Baysinger \& Henry N. Butler, Corporate Governance and the Board of Directors: Performance Effects of Changes in Board Composition, 1 J.L. ECON. \& ORG. 101, 113 (1985).

243 Data reported by Marshall Small, The Evolving Role of the Director in Corporate Governance, 30 HASTINGS L.J. 1353, 1358 (1979).

$244 \quad I d$.

245 Id.; SECURITIES AND EXChANGE COMMISSION, StAFF REPORT ON CORPORATE ACCOUNTABILITY F99 (1980).

246 George Melloan, A Good Director is Getting Harder to Find, WALL St. J., Feb. 9, 1988, 39. 
provided high-profile evidence of change in the boardroom. ${ }^{247}$ The pattern appeared to be sustained through the remainder of the decade. Jay Lorsch, author of a 1989 book on boards entitled Pawns and Potentates, ${ }^{248}$ suggested in 2001 that during the 1980s directors "were more like the pawns. Today they are more like the potentates."249 ${ }^{24 a w}$ professor Ronald Gilson similarly asserted "Directors are now energized." 250

Such optimism concerning boards proved to be somewhat premature. In the early 2000s, sizeable public companies such as Enron, WorldCom, Adelphia Communications and Tyco were laid low by major scandals. Amidst a sharp jump in media coverage of corporate governance, ${ }^{251}$ boards were identified as major culprits. ${ }^{252}$ Forbes said in 2003 of major scandal-afflicted public companies "(a)ll had boards of directors that looked the other way while their chief executives ran roughshod over the auditing committees and often fattened their personal bank accounts while the businesses fell apart."253

Policymakers concurred that the scandals demonstrated there were problems in the boardroom and acted accordingly. The Sarbanes-Oxley Act of 2002 (SOX), which was the primary regulatory response to the managerial misfeasance, mandated the establishment of audit committees composed entirely of independent directors. ${ }^{254}$ The same year the New

\footnotetext{
$247 \quad$ Cheffins, supra note 56, 59.

248 JAY W. LORSCH, PAWNS AND POTENTATES (1990).

249 The Professor: Jay Lorsch, DIRECTORS \& BOARDS, Fall 2001, 18, 18.

250 Ronald Gilson, Unocal Fifteen Years Later (And What We Can Do About It), 26 DEL.
} J. CORP. L. 491, 513 (2001).

251 Lucian A. Bebchuk, Alma Cohen \& Charles C.Y. Yang, Learning and the Disappearing Association Between Governance and Returns, 108 J. FIN. ECON. 323, 324, 330 (2013).

$252 \quad$ Cheffins, supra note 13, 738.

253 Michael K. Ozanian \& Scott Decarlo, Does the Board Have a Backbone?, ForBeS, May 12, 2003, 106.

254 Sarbanes-Oxley Act of 2002, Pub. L. 107-204, 116 Stat. 745, s. 301. 
York Stock Exchange promulgated listing rules that required listed companies to have boards with at least a majority of independent directors and to have nomination and compensation committees staffed exclusively by independent directors. ${ }^{255}$ NYSE rival NASDAQ adopted similar if somewhat less exacting requirements. ${ }^{256}$

There was optimism following the adoption of SOX that boards had evolved into reliable monitors of public company executives. Alan Murray, in his 2007 book Revolt in the Boardroom, said due to post-scandal changes "CEOs had to take their boards much more seriously" and directors, "no longer handpicked" by the chief executive, were "acting with new energy" as part of a "shift in power from the chief executive's office to the corporate boardroom." 257 Boards were not yet functioning optimally, however. They were singled out for criticism, for instance, when the financial crisis of 2008 hit, with bank directors being accused of helping to bring on the crisis by failing to keep freewheeling executives in check. ${ }^{258}$ Nevertheless, boards, as compared with their counterparts in the 1950s and 1960s, were operating as a considerably more robust accountability mechanism.

\section{B. Shareholders}

While the retail investors who collectively dominated share ownership during the managerial capitalism era were ill-suited to engage in activism, during the 1970s and 1980s institutional investors better situated to intervene due to their "power and sophistication" 259

255 Donald C. Clarke, Three Concepts of the Independent Director, 32 DEL. J. CoRP. L. 73,88 (2007).

256 Id. at 89-91; Raymond Gilmartin, The Argument for a Lead Director in THE FUTURE OF BoARDS: MEETING THE GOVERnANCE CHALlENGES OF THE TwENTY-FIRST CENTURY 155, 160 (Jay W. Lorsch, ed., 2012).

257 MURRAY, supra note 189, xvii, 265.

258 Carl C. Icahn, The Economy Needs Corporate Governance Reform, WALL ST. J., Jan. 23, 2009, A13.

259 Supra notes 64-67 and accompanying text; EISENBERG, supra, note 16, 56-57. 
were steadily displacing retail investors as share owners (Figure 4). This trend did not yield a marked change in practice, however, with the intensity of shareholder monitoring.

Investment managers acting on behalf of institutional shareholders feared intervening in the affairs of an underperforming company was unlikely to be worthwhile. Activism was thought to be a potentially costly, disruptive and time-consuming endeavor that was unlikely, in the event of success, to have a significant beneficial impact on an investment portfolio comprising dozens of stocks. ${ }^{260}$ Also, regulation, such as rules putting investment funds under an onus to diversify their holdings, created obstacles for institutional investors perhaps otherwise inclined to engage in activism. ${ }^{261}$

Figure 4: U.S. Corporate Stock Held by Households and Institutions, 1970-1990

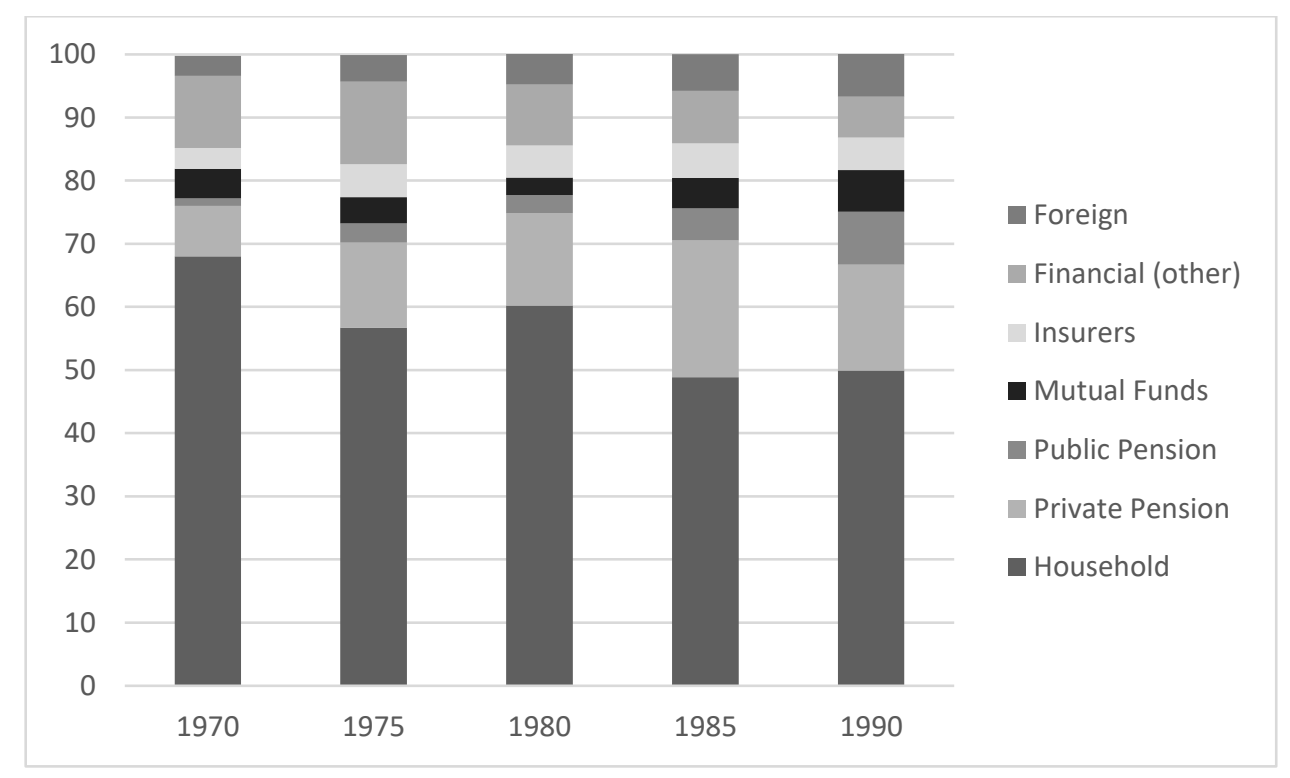

Source: OECD $(1996)^{262}$

260 Cheffins, supra note 3 , xx.

261 Mark J. Roe, Strong Managers, Weak Owners: The Political Roots of AMERICAN CORPORATE FINANCE 104-5, 138-39 (1994).

OECD, OECD ECONOMIC SURVEYS -- UNITED STATES 124 (1996). 
During the 1990s institutional investors generally continued to shy away from taking on a substantial "hands on" corporate governance role. ${ }^{263}$ Their actions, however, helped to ensure indirectly that the generation of shareholder value was sustained as a top priority for public company executives. During the 1950s and 1960s, it was widely assumed that shareholders were merely one constituency among several executives would take into account, with the interests of employees, suppliers and customers also being crucial. ${ }^{264} \mathrm{~A}$ wave of hostile takeovers in the 1980s moved stockholders up the priority list as the fate of management hinged to an unprecedented degree on shareholder perceptions of the capabilities of incumbent executives. ${ }^{265}$

Hostile takeover activity fell off markedly as the 1990s began. ${ }^{266}$ Apprehension ensued that managerial accountability would erode, particularly in relation to shareholders. ${ }^{267}$ Institutional investors, mindful of the need for substitute strategies to motivate management to focus on shareholder interests, lobbied the corporate sector successfully to displace a traditional bias toward linking levels of executive pay with the size of the company involved in favor of correlating compensation with stockholder returns. ${ }^{268}$ Public company executives in turn became preoccupied with the earnings of the companies they were running, knowing

263 Brian R. Cheffins, The History of Corporate Governance in THE OXFORD HANDBOOK OF CORPORATE GOVERNANCE 46, 54 (Mike Wright et al. eds., 2013).

264 Cheffins, supra note 13, 730.

265 Id. at 731.

266 John Weir Close, A Giant Cow-Tipping by SAVAges: The Boom, Bust And Boom CUlTuRE OF M\&A 160-64 (2013).

267 Cheffins, supra note 13, 732.

268 Frank Dobbin \& Dirk Zorn, Corporate Malfeasance and the Myth of Shareholder Value, 17 Political Power \& Social Theory 179, 189 (2005). 
that failure to match investor expectations could "kill a stock" and thereby preclude pay-outs under potentially lucrative performance-oriented compensation schemes. ${ }^{269}$

The predilection for passivity affecting "mainstream" institutional shareholders did not change markedly in the 2000s. When corporate scandals struck at the beginning of the decade, institutional investors were criticized for being "sleeping giants" that were "shockingly indifferent to bad management" and for standing by when it should have been evident that boards were not up to scratch. ${ }^{270}$ As the financial crisis of 2008 mounted asset managers acting on behalf of major institutional shareholders generally prized stability and correspondingly refrained from rocking the boat even in companies seemingly poised to suffer major financial setbacks. ${ }^{271}$

While mainstream institutional shareholders retained their bias in favor of passivity from the 1970s through to the 2000s, shareholder pressure on public company executives would intensify following 2000. This was due to hedge funds coming to prominence that specialized in targeting underperforming companies and lobbying for changes to boost shareholder returns. ${ }^{272}$ The modus operandi of the sub-set of hedge funds that engaged in activism was to accumulate quietly a sizeable strategic holding, make proposals that management unlock shareholder value by off-loading weak divisions, distributing cash to

269 Gretchen Morgenson, Forecasts Made Rosy for Investors, But Results Are Sometimes Paler, NY TIMES, Dec. 21, 1999, A1; Dirk Zorn et al., Managing Investors: How Financial Markets Reshaped the American Firm in ThE SOCIOLOGY OF FINANCIAL MARKETS 269, 277 (Karin Knorr-Cetina \& Alex Preda, eds., 2005).

$270 \quad$ Is Greed Good?, ECONOMIST, May 18, 2002, Survey of International Finance, 23; A Helluva Problem, ECONOMIST, Sept. 21, 2002, 81; JOHN NOFSINGER \& KENNETH KIM, INFECTIOUS GREED: RESTORING CONFIDENCE IN AMERICA'S COMPANIES 197 (2003). 271 Brian R. Cheffins, Did Corporate Governance "Fail" During the 2008 Stock Market Meltdown? The Case of the $S \& P 500,65$ Bus. LAw. 1, 47-49 (2009).

272 Brian R. Cheffins \& John Armour, The Past, Present, and Future of Shareholder Activism by Hedge Funds, 37 J. CORP. L. 51, 58, 60-61, 80-82 (2011). 
shareholders or even selling the company, and then count on support from other shareholders to maximize pressure on management. ${ }^{273}$

In 2001, the Wall Street Journal drew attention to the fact "hedge-fund managers, who historically have been relatively passive" were beginning to push "companies to find new ways to unlock shareholder value." 274 Activist hedge funds then rocketed to governance prominence. The New York Times indicated in 2007 "a wide-ranging, merry band of hedge fund managers have risen to power by holding their poison pens to the throats of corporate executives and directors" with the results being "staggering: activists have put dozens of companies, large and small, into play and helped prop up the stock price of dozens of others." 275 Hedge funds were characterized in 2008 as "the newest big thing in corporate governance."276 In a 2010 law review article where law professors Marcel Kahan and Edward Rock described U.S. chief executives as "embattled" they cited hedge fund activism as a cause in addition to reforms concerning independent directors that resulted in CEOs losing power to boards. ${ }^{277}$

\section{CORPorate GOVERnANCE ANd COUNTERVAILING POWERS TODAY}

From the 1970s through to the opening decade of the 2000s, internal accountability mechanisms in public companies strengthened, albeit fitfully. Boards were restructured in a manner that reinforced their monitoring capabilities and shareholders edged away from their bias in favor of passivity, especially with the arrival of hedge fund activists. One might infer

\footnotetext{
$273 \quad I d$. at 57, 60, 64-65.
}

274 Robin Sidel, More Investors Turn Activist in Tough Times, WaLl St. J., April 13, 2001, C1.

275 Andrew Ross Sorkin, Will the Credit Crisis End the Activists' Run?, N.Y. TIMES, Aug. 26, 2007, B7.

276 Jonathan R. Macey, Corporate Governance: Promises KePt, Promises BROKEN 241 (2008).

277 Kahan \& Rock, supra note 64, 989-90. 
from these trends that, consistent with a corporate governance predilection to focus on “internal" accountability mechanisms, ${ }^{278}$ "external" constraints on managerial discretion were destined to become a mere afterthought. At present, however, it is open to question whether the trend in favor of boards and shareholders exerting greater control over public company executives will continue. Correspondingly, for the foreseeable future "external" constraints are destined to remain an important determinant of the scope of managerial discretion. At the same time, though, with each of the countervailing powers we have considered - unions, pressure from rivals and regulation - there is reason to doubt in the near- to medium-term their potency as a check on managerial discretion.

\section{A. Internal Accountability Mechanisms}

While since the mid- $20^{\text {th }}$ century boards have evolved in a manner that has facilitated their monitoring capabilities, there may well be little scope for further movement in that direction. Board reform remains a topic for debate, but the emphasis has begun to shift to different objectives. As for shareholders, hedge fund activists, who emerged as significant corporate governance players in the 2000 s, may be in a position similar to boards in that they appear not to have much new to add with respect to fostering managerial accountability.

Otherwise, the growing popularity of investment in funds that track well-known stock market indices may well bolster executive autonomy due to a bias in favor of passivity on the part of these index trackers.

\section{Boards}

Board reform was part of the financial crisis-driven reform package the Dodd-Frank Act of 2010 introduced but circumstances muted the impact of leading changes. For instance, a measure mandating that stock exchange listing rules require that publicly traded companies

$278 \quad$ Supra note 4 and related discussion. 
have an independent compensation committee was largely superfluous because NYSE listing rules already imposed this requirement and the NASDAQ listing rules were structured similarly. ${ }^{279}$ In addition, a 2011 judicial ruling striking down a draft SEC regulation rendered at least temporarily moot a Dodd Frank provision affirming that the SEC could promulgate a "proxy access" rule giving dissident stockholders seeking board representation the opportunity to use the proxy documentation their corporations circulate to communicate to their fellow shareholders. ${ }^{280}$

Despite factors muting Dodd-Frank’s impact on boards, “(t)o a significant extent, the dreams of yesterday's corporate governance advocates have come true." 281 The monitoring model of the board that achieved notoriety in the 1970s implied that outside directors should substantially outnumber executives on the board and that boards should establish audit, compensation and nomination committee staffed by such directors. ${ }^{282}$ This is what we currently see. As of 2017,85 percent of directors of S\&P 500 companies qualified as “independent", up from 80 percent in 2007. ${ }^{283}$ Partly due to reforms introduced in the early 2000s by SOX and by stock exchanges that went a considerable distance toward making

279 Dodd-Frank Act, s. 952; supra note 255 and accompanying text; Kevin J. Murphy, Executive Compensation: Where We Are, and How We Got There, in 2A HANDBOOK OF THE ECONOMICS OF FINANCE 211, 312 (George M. Constantinites et al. eds., 2013).

280 Dodd-Frank Act, s. 971; John C. Coffee \& Darius Palia, The Wolf at the Door: The Impact of Hedge Fund Activism on Corporate Governance, 41 J. CoRP. L. 545, 570-71 (2016).

281 Mariana Pargendler, The Corporate Governance Obsession, 42 J. CORP. L. 359, 401 (2016).

Supra notes 239-41 and related discussion. 
audit, compensation and nomination committees staffed by independent directors mandatory, ${ }^{284}$ such committees are now essentially universal in large public companies. ${ }^{285}$

Incentives directors have to monitor executives may well have been bolstered by changes corporations have made to director election procedures that reputedly have "handed investors the keys" to public company boardrooms. ${ }^{286}$ There was during the 2000s a substantial move away from "staggered" boards that can delay the assumption of control by an insurgent shareholder with sufficient voting clout to a win a proxy contest for board seats. ${ }^{287}$ The trend has continued, with only 24 percent of S\&P 500 companies having staggered boards in 2011 and just 8 percent in $2017 .^{288}$ Similarly, the proportion of S\&P 500 companies with "majority" rather than "plurality" voting, meaning a nominee has to obtain a majority of votes cast to be elected even when running unopposed, stood at 89 percent in 2018 as compared with 16 percent in $2006 .{ }^{289}$ While the 2011 judicial ruling on proxy access was a setback for the SEC, more than three out of five S\&P 500 companies have changed

284 Supra notes 254-56 and accompanying text; SPENCERSTUART, supra note 283, 29 (noting that stock exchange listing requirements are not applicable to companies with controlling shareholders).

285 SPENCERSTUART, supra note 283, 29 (indicating that 100 percent of S\&P 500 companies had an audit and compensation committee staffed entirely by independent directors, as did 99.6 percent with nomination committees).

286 Joann S. Lublin, Investors Gain More Clout Over Boards, WALL ST. J., Jan. 11, 2016, B1.

287 Ram Charan, Denis Carey \& Michael Useem, BoARds That LeAD: When to TAke Charge, When to Partner, And When to Stay Out OF The Way 17, 245 (2013). 288 SPENCERStUART, supra note 283, 16; Liz Hoffman, Bidders Pounce on Firms' Weakened Defenses, Wall ST. J., Aug. 26, 2014, C1.

289 Claudia H. Allen, Study of Majority Voting in Board Elections, Neal, Gerber \& Eisenberg, Nov. 12, 2007, 1, available at http://www.nge.com/files/uploads/documents/majoritystudy111207.pdf (accessed June 19, 2018) (indicating additionally that the figure had increased to 66 percent at the time of writing); EY Center for Board Matters, Corporate Governance by the Numbers, Feb. 28, 2018, available at http://www.ey.com/us/en/issues/governance-and-reporting/ey-corporategovernance-by-the-numbers (accessed April 6, 2018). 
their by-laws to introduce the procedure for significant shareholders, up from about 21 percent in early 2016 and just 1 percent in $2014 .{ }^{290}$

Anecdotally, structural changes affecting boards have been matched by changes in practice bolstering the effectiveness of boards as monitors of executives. Rav Gupta, a former CEO of a Fortune 500 chemical concern and an outside director of additional Fortune 500 companies, maintained in 2016 "we have moved the needle a lot in the last 15 years", emphasizing " "radical change' in the boardroom" since the financial crisis. ${ }^{291}$ The New York Times suggested in 2017 boards "have changed, evolving from country club like collections of the same familiar faces into a much more diverse and demanding constituency."292

While boards' monitoring capabilities have improved, calls for additional boardroom reform will no doubt continue. There are concerns that "(m)any boards lack the time necessary to fulfill their monitoring obligations and oversee management." 293 With women holding not even one out of four S\&P 500 directorships, fostering increased diversity in the boardroom stands out as an obvious priority. ${ }^{294}$ The case has also been made that boards should move beyond monitoring and take on a leadership role by actively partnering with management in the formulation of corporate strategy. ${ }^{295}$

290 EY Center for Board Matters, supra note 289; Joann S. Lublin, Big Firms Resist Boardroom Entry, Wall ST. J., April 18, 2017, B2.

291 The Role of Corporate Boards: A Roundtable Discussion of Where We're Going and Where We've Been, J. APP. CORP. FIN., Winter 2017, 22, 25-26.

292 Nelson D. Schwartz, Decline of the Baronial CEO, N.Y. TIMES, June 18, 2017, Business, 1.

293 Nicola Faith Sharpe, The Cosmetic Independence of Corporate Boards, 34 SEATTLE U. L. REV. 1435, 1436, 1453 (2011).

$294 \quad$ Pargendler, supra note 281, 392; SPENCERSTUART, supra note 283, 21; Vanessa Fuhrmans, Pressure Tactics Diversify Boards, WALl St. J., April 26, 2018, B8.

295 Charan, CAREy \& UsEem, supra note 287; IrA M. Millstein, The ACTIVIST DIRECTOR: LESSONS FROM THE BOARDROOM AND THE FUTURE OF THE CORPORATION vii, 17982 (2017). 
While board reform is destined to remain on the agenda, there appears to be little additional scope for boards to be restructured to constrain management through monitoring. With independent directors dominating boards, with the board committees assumed to be crucial from a governance perspective being all but universal and with shareholders minded to turf out underperforming directors having increased theoretical scope to do so, there are few obvious moves left to upgrade the board's capacity to scrutinize executive behavior. The fact that outside directors are part-timers imposes inevitable limitations on their ability to act as corporate watchdogs, but reputedly boards work noticeably harder than they used to. ${ }^{296}$ Hence, it seems unlikely that boards will operate as a markedly more robust check on corporate executives in the future than they do currently.

\section{Shareholders}

Hedge funds, as "the newest big thing in corporate governance", bolstered considerably the potency of shareholder-related constraints on managerial behavior during the 2000s. ${ }^{297}$ The turmoil associated with the 2008 financial crisis posed challenges for hedge fund activists but interventions continued, albeit not quite as frequently as during the mid-2000s. ${ }^{298}$ Hedge fund activism then went into overdrive as the 2010s got underway, with academics Jack Coffee and Darius Palia saying in 2016 it had "recently spiked, almost hyperbolically.",299

A by-product of the work of the hedge fund provocateurs has been to nudge mainstream institutional shareholders -- “America's lazy money" -- at least partially off the

296 Geoff Colvin, Inside the Boardroom: The Party Is Over!, Fortune, May 20, 2013, 219; Jay W. Lorsch, America's Changing Corporate Boardrooms: The Last Twenty-Five Years, 3 HARV. Bus. L. REV. 119, 130 (2013).

297 Supra notes 275-77 and related discussion.

298 Cheffins \& Armour, supra note 272, 95-96.

299 Coffee \& Palia, supra note 280, 548. 
sidelines. ${ }^{300}$ Since hedge fund activists only acquire minority stakes in companies they target, they know management can ignore them unless other shareholders are sympathetic. During the 2000s, hedge funds proved quite successful in rallying major institutional investors to back their dissident campaigns. ${ }^{301}$ This continued as the 2010s got underway. Mainstream institutional investors were often favorably disposed toward hedge fund interventions and institutional backing in its turn frequently represented sufficient voting power to swing around otherwise recalcitrant executives of targeted companies. ${ }^{302}$ The result, according to law professors Ronald Gilson and Jeff Gordon, was a "happy complementarity" resulting in "better monitoring" that lowered managerial agency costs and in "governance markets" becoming "more complete." 303

Though hedge funds have fostered more intense monitoring of public company executives, hedge fund activism may also have reached an inflection point marking the end of the upward trajectory that began in the early 2000s. ${ }^{304}$ Public company executives, realizing they can end up on the back foot once a hedge fund activist arrives, are increasingly taking advance precautions. Reputedly, “'think like an activist' has become a boardroom mantra as companies strive to anticipate potential hedge fund demands and address perceived weaknesses."305 Numerous companies have, for instance, been engaging in activist "fire

\footnotetext{
$300 \quad$ Capitalism's Unlikely Heroes, ECONOMIST, Feb. 7, 2015, 11.
}

$301 \quad$ Cheffins \& Armour, supra note 272, 87.

302 Ronald J. Gilson \& Jeffrey N. Gordon, The Agency Costs of Agency Capitalism: Activist Investors and the Revaluation of Governance Rights, 113 COLUM. L. REV. 863, 89697 (2013).

$$
303 \quad I d \text {. at } 898,917 .
$$

304 Stephen Foley, The So-Called Death of Event-Driven Investing, FIN. TIMES, March 7, 2016, FT fm, 10.

305 Ajay Khorana, Anil Shivdasani \& Gustav Sigurdsson, The Evolving Shareholder Activist Landscape (How Companies Can Prepare for It), J. APP. CORP. FIN., Summer 2017, 8,10 . 
drills", identifying areas of vulnerability and making changes so as to try to forestall a hedge fund foray. ${ }^{306}$ With public companies reading the activism playbook and taking anticipatory measures, hedge funds seem to be pulling back as they realize there are fewer instances where intervening will add value. ${ }^{307}$ The number of activist forays indeed declined substantially in 2016 and 2017 as compared to 2014 and 2015, particularly among large public companies. ${ }^{308}$

Data for the first few months of 2018 suggest the decline in hedge fund interventions may have ended, at least temporarily. ${ }^{309}$ Another trend, however, should, if it persists, preclude a meaningful enduring surge in hedge fund activism. Activist hedge funds have, on average, been delivering poor returns lately. ${ }^{310}$ Perhaps with public company executives endeavoring to think like activists there are now few instances where underperformance is

306 David Gelles, Boardrooms Rethink Tactics to Defang Activist Investors, N.Y. TIMES, Nov. 12, 2013, F10.

307 David Benoit, Activists Start Thinking Smaller, WALL ST. J., Nov. 15, 2016, A1; Stephen Foley, The Hard Task of Working Out Where Activists Will Pounce, FIN. TIMES, Jan. 24, 2017, 28.

308 Khorana, Shivdasani \& Sigurdsson, supra note 305, 8; FactSet, 2016 Shareholder Activism Review, Feb. 1, 2017, 7-8, available at https://insight.factset.com/hubfs/Resources/Research\%20Desk/Market\%20Insight/FactSet\%2 7s\%202016\%20Year-End\%20Activism\%20Review_2.1.17.pdf (accessed June 23, 2018) (the proportion of campaigns involving companies with market capitalizations exceeding $\$ 10$ billion fell from 8 percent in 2015 to 5 percent to 2016); Mike Coranto, 2017 Proxy Fights: High Cost, Low Volume, FACTSET INSIGHT, November 6, 2017, available at https://insight.factset.com/2017-proxy-fights-high-cost-low-volume ("high impact" campaigns fell from 382 in 2015 to 328 in 2016 and 273 in 2017) (accessed June 28, 2018). 309 Cara Lombardo, Activists Turn Up Heat in Drive for Returns, WaLl ST. J., July 13, 2018, B1.

$310 \quad I d$.; Jeffrey A. Sonnenfeld, The CEOs Who Didn't Deserve the Boot, WALL ST. J., July 13, 2017, A15; Leslie Picker, Hedge Fund Industry's Stars are Stumbling as Stock Picks and Proxy Fights Fizzle, CNBC.COM, January 23, 2018, available at https://www.cnbc.com/2018/01/23/wall-streets-star-activists-stumbled-in-2017.html (accessed June 27, 2018); David Benoit, Investors Flee Star Activist Ackman, WALL ST. J., April 6, 2018, A1; Gregory Zuckerman, A Hedge-Fund Star Dims, And Investors Bolt, WALL ST. J, July 5, 2018, A1. 
sufficiently egregious for intervention to yield bumper returns. Whatever the explanation, investors, disappointed with results activist hedge funds have been delivering, have begun taking their money out of the sector, a trend that inevitably would throw the brakes on activist hedge fund growth if it continues in earnest. ${ }^{311}$ Hedge fund activism thus appears to be stalling, even if there is no full-scale retreat on the horizon.

If in fact a ceiling is coming into view for hedge fund activism, the stance taken by pension funds and mutual funds, as mainstream institutional investors, will dictate the extent to which shareholder pressure continues to strengthen as a managerial accountability mechanism. Generally speaking their bias in favor of passivity continues. ${ }^{312}$ Investment bankers Joseph Perella and Peter Weinberg have argued, for example, "the big shareholders, the institutional shareholders who invest for pension funds and the like, need to stop being silent and speak out." 313 Without a change in this regard, shareholder action may well have peaked as a constraint on managerial discretion.

While the basic reticent stance of mainstream institutional shareholders remains unchanged there is a recent twist in the plot of which account must be taken. A dramatic increase in the popularity of "passive" index tracking funds has reportedly resulted in "a concentration of ownership not seen since the days of the Rockefeller Trust" oriented around Standard Oil at the turn of the $20^{\text {th }}$ century. ${ }^{314}$ Reputedly, the "passive funds are the new king of our capital markets" and their growth "is transforming the governance landscape." 315

\footnotetext{
$311 \quad$ Foley, supra note 307; Benoit, supra note 310.

312 Gilson \& Gordon, supra note 302, 888-89.

313 Joseph Perella \& Peter Weinberg, Powerful, Disruptive Shareholders, N.Y. TIMES,
} April 9, 2014, A23.

314 Burton G. Malkiel, Index Funds Still Beat 'Active' Portfolio Management, WALL ST. J., June 6, 2017, A17.

315 Jill Fisch, Assaf Hamdani \& Steven Davidoff Solomon, Passive Investors, University of Pennsylvania Institute for Law and Economics Working Paper 18-12 15, 43 (2018). 
Big index tracker funds drive down fees investors pay by exploiting economies of scale and by deploying a plain vanilla investment approach, namely matching the performance of a stock market index such as the S\&P 500. ${ }^{316}$ For instance, the expense ratio for the main S\&P tracker fund which the Vanguard Group operates is 0.04 percent of the fund's assets, as compared with 0.8 percent for the average actively managed mutual fund..$^{317}$ The logic of index tracking funds has been winning over investors. Fresh investment meant the proportion of the S\&P 500 owned by U.S.-based index trackers increased from 4.6 percent in 2005 to 13.9 percent in $2017 . .^{318}$

The three largest U.S.-based asset management firms, BlackRock, Vanguard, and State Street, dominate the rapidly growing index tracking industry. ${ }^{319}$ With a substantial majority of the equity under management of each of "the Big Three" being invested in a passive manner, ${ }^{320}$ the dramatic growth of index tracking has meant their stakes in public companies have increased substantially recently. Vanguard's passive funds alone held a stake of 5 percent or more in 468 S\&P 500 companies as of 2016, up from just three in 2005. ${ }^{321}$ The proportion of S\&P 500 companies where BlackRock, Vanguard, and State

316 John C. Bogle, The Clash of Cultures: InVestment vs. SPECUlation 179, 319 20 (2012); The Big Squeeze, Economist, May 13, 2017, 74.

$317 \quad$ Big Squeeze, supra note 316.

318 Chris Dieterich, Maureen Farrell \& Sarah Krouse, S\&P 500 Blocks Multiple Classes, Wall ST. J., Aug. 2, 2017, B1.

319 Jan Fichtner, Eelke M. Heemskerk \& Javier Garcia-Bernardo, Hidden Power of the Big Three? Passive Index Funds, Re-Concentration of Corporate Ownership, and New Financial Risk, 19 Bus. \& POLITICS 298, 304 (2017).

$320 \quad$ Id.; Hortense Bioy et al., Passive Fund Providers Take an Active Approach to Investment Stewardship, MORNINGSTAR, Nov. 2017, 4.

321 Sarah Krouse \& David Benoit, Passive Funds Embrace Their New Power, WALL ST. J., Oct. 25, 2016, A1. 
Street combined would constitute the largest shareholder increased from 25 percent in 2000 to 88 percent in $2015 .{ }^{322}$

The large collective stake the Big Three hold in U.S. public companies has been referred to as "(a)n economic blockbuster" that "has recently been exposed." 323 Rhetoric deployed by key index trackers imply closer scrutiny of management is accompanying the ownership shift. BlackRock CEO Larry Fink, who reputedly wants "to be the conscience of Corporate America," 324 maintains "(t)he time has come for a new model of shareholder engagement — one that strengthens and deepens communication between shareholders and the companies that they own." ${ }^{325}$ Similarly Glenn Booraem, a Vanguard principal and head of investment stewardship, has said its funds seek to be "passive investors but active owners." ${ }^{326}$ Booraem reasons Vanguard and other investment firms operating index tracking funds must exercise their voices because with the level of investment in companies being predetermined by the market “(w)e're riding in a car we can't get out of" and "(g)overnance is the seat belt and air bag." 327

322 Dorothy Shapiro Lund, The Case Against Passive Shareholder Voting, 43 J. CORP. L. 493, 496, 509 (2018); Fiona Scott Morton \& Herbert Hovenkamp, Horizontal Shareholding and Antitrust Policy, 127 YALE L.J. 2026, 2029 (2018).

323 Einer Elhauge, Horizontal Shareholding, 129 HARV. L. REV. 1267, 1267 (2016). Elhuage also treats Fidelity, a major asset manager which does not specialize in passive investing, as part of the "economic blockbuster" phenomenon.

324 BlackRock: Ebb and Flow, FIN. TIMES, April 13, 2018, 12.

325 Sarah Krouse, BlackRock's Fink Pledges to Intensify Shareholder Activism, WALL ST. J., January 17, 2018, B12.

326 Reinventing the Company, ECONOMIST, Oct. 24, 2015, 11; Conference Board, Glenn Booraem, available at https://www.conference-board.org/bio/index.cfm?bioid=2944 (accessed July 16, 2018).

327 Amy Deen Westbook \& David A. Westbook, Unicorns, Guardians, and the Concentration of the U.S. Equity Markets, 96 NEB. L. REV. 688, 736 (2018). See also Fisch, Hamdani \& Davidoff Solomon, supra note 315, 14-19. 
Consistent with BlackRock and Vanguard's rhetoric, the Big Three have added staff recently to deal with governance and stewardship. ${ }^{328}$ Nevertheless, each of the firms is poorly situated to impinge substantially on the discretion of public company executives. BlackRock's governance team is comprised of around 35 employees tasked with overseeing the 14,000 companies in which BlackRock owns shares. ${ }^{329}$ Vanguard has just over 20 people for its 13,000 companies and State Street has approximately a dozen for its $9,000 .^{330}$ The governance teams of the Big Three carry out dozens of engagements each year with executives of companies in which their index tracking funds own shares. ${ }^{331}$ Nevertheless, with most portfolio companies it is not feasible to arrange a meeting even annually. ${ }^{332}$ The head of corporate governance for State Street's asset management funds has told her team that because of time constraints they should not agree to every meeting company executives might request. ${ }^{333}$ Public company executives notice. A CEO told the Financial Times in 2017 '(w)e'd love to talk to the passive guys, they control 20 per cent of our shares, but they don’t want to see us." 334

Given the modest amount of direct contact between the Big Three indexers and public companies in which they own shares, anything approaching the sort of firm-specific

328 Fisch, Hamdani \& Davidoff Solomon, supra note 315, 26; Jason Zweig, This Index Argument Does Not Hold Water, Wall ST. J., April 21, 2018, B1.

$329 \quad$ Bioy et al., supra note 320, 19; Krouse \& Benoit, supra note 321.

$330 \quad$ Bioy et al., supra note 320, 19; Lund, supra note 322, 516; Attracta Mooney \& Robin Wigglesworth, Biggest Fund Managers Face Showdown in US Gun Debate, FIN. TIMES, March 5, 2018, FTfm, 6.

331 Bioy et al., supra note 320, 16 (listing 1480, 817 and 611 for BlackRock, Vanguard and State Street respectively for 2016). See also Fisch, Hamdani \& Davidoff Solomon, supra note $315,25$.

$332 \quad$ Lund, supra note 322, 516, 519.

$333 \quad$ Krouse \& Benoit, supra note 321.

334 John Authers, How Passive Investors Morphed Into the Bad Guys, FIN. TIMES, Oct. 14, 2017, 24. 
meddling in which activist hedge funds engage is unrealistic. BlackRock's head of corporate governance has acknowledged '(i)t's not the shareholders' role to second guess what management is doing in every single issue." ${ }^{335}$ More broadly, index trackers, given their business model, are unlikely to emerge as vigilant monitors of public company executives any time soon. Any highly diversified investment fund will have a bias in favor of passivity because of the costs associated with activism and because a successful intervention is unlikely to have a significant impact on stock portfolios encompassing numerous companies. ${ }^{336}$ Index tracker funds have particularly weak incentives to act as engaged shareholders. ${ }^{337}$ Operators of tracker funds do not compete over the performance of the index they are set up to mimic, which is taken as a given, and instead focus on keeping costs as low as possible and on eliminating tracking errors. ${ }^{338}$ Correspondingly, if those running an index fund expend meaningful resources to identify and correct underperformance in particular companies, any gains will be shared with the market at large, fees will increase and market share will likely be lost rapidly to cheaper, fully passive rivals in an industry where fee competition has a significant effect on investor inflows. ${ }^{339}$

Only time will tell exactly what corporate governance role BlackRock, Vanguard and State Street will assume. ${ }^{340}$ At present, though, it is unlikely that the growth of passive

\footnotetext{
$335 \quad$ Krouse \& Benoit, supra note 321.

336 Supra note 260 and related discussion.

337 Lucian A. Bebchuk, Alma Cohen \& Scott Hirst, The Agency Problems of Institutional Investors, 31 J. ECON. PERSP. 89, 90 (2017).

338 Edward B. Rock \& Daniel L. Rubinfeld, Defusing the Antitrust Threat to Institutional Investor Involvement in Corporate Governance, New York University School of Law Law and Economics Research Series Working Paper No. 17-05, 7, 27 (2017).

339 Bebchuk, Cohen \& Hirst, supra note 337, 98; Passive, Aggressive, EcONOMIST, Nov. 18, 2017, 69; Chris Flood, Price War Becomes “Winner Take All”, Fin. TiMES, May 2, 2018, FTfm, 1 . 
indexers will substantially compromise existing managerial prerogatives in public companies in the foreseeable future. If in addition there has been an inflection point with hedge fund activism marking the end of its upward trajectory, then, as with boards, shareholders are unlikely to operate as a markedly more robust check on corporate executives any time soon.

\section{B. External Accountability Mechanisms}

This article has already achieved its two core objectives. First, the analysis of managerial accountability in the 1950s and 1960s has shown that external mechanisms sources of countervailing power -- can play a substantial role in constraining the discretion of public company executives. Second, the historical overview of internal accountability mechanisms, traced forward to the present day, has revealed that while boards and shareholder action have developed into considerably more potent checks on executive discretion than they were during the heyday of managerial capitalism limits are coming clearly into view. Hence, for the foreseeable future external constraints are destined to remain an important determinant of the scope of managerial discretion.

While the core ideas underpinning this article have now been developed, the reader should not be left guessing as to the current state of play with governance-related sources of countervailing power John Kenneth Galbraith identified in the 1950s. As we will see now, unions remain an afterthought. With regulation, there has been something of a deregulatory revival under the Trump presidency but governmental rule-making should remain a meaningful constraint for public company executives for the foreseeable future. Finally, while pressure from rivals emerged as a potent external constraint on managerial discretion as the $20^{\text {th }}$ century drew to a close, concerns are emerging that various large firms are accumulating sufficient market power to preclude meaningful challenges by rivals.

\section{Unions}


Following the managerial capitalism era, unions receded steadily in importance as a variable with which management had to be concerned. ${ }^{341}$ Organized labor's decline has not been reversed lately. Union density slumped to 10.7 percent of the workforce in 2016, an alltime low, and remained unchanged in $2017 .{ }^{342}$ With private sector employers, only 6.5 percent of workers were unionized in 2017, a proportion just fractionally above the all-time low of 6.4 percent in $2016 .{ }^{343}$ Strike activity has continued to decline as well. Between 2010 and 2017 there was an average of 14 major work stoppages annually, a decline from the already historically low rate of 20 per year in the 2000 s. ${ }^{344}$

A marked improvement in organized labor's fortunes seems unlikely. In the private sector context an ideal setting to put collective bargaining in place is a large workplace staffed by a sizeable contingent of full-time employees. ${ }^{345}$ This arrangement, however, has become very much the exception to the rule with employers depending heavily on automation and outsourcing to economize on labor costs. ${ }^{346}$ Continued antipathy towards unions in the southern U.S. and in sectors such as high-tech and restaurants has also hamstrung organized labor. ${ }^{347}$ The upshot is that unions are unlikely to return soon as a highly relevant constraint for public company executives.

\footnotetext{
$341 \quad$ Supra notes 146-54 and accompanying text.

$342 \quad$ Unionstats.com, supra note 146.

$343 \quad I d$.

$344 \quad$ Bureau of Labor Statistics, supra note 147.

345 William E. Forbath \& Brishen Rogers, New Workers, New Labor Laws, N.Y. TIMES,
} Sept. 4, 2017, A21.

346 Labour Pains, ECONOMIST, Nov. 2, 2013, 73; Lauren Webb, The End of Employees, Wall St. J., Feb. 2, 2017, A1.

347 Gregory Ferenstein, Why Labor Unions And Silicon Valley Aren't Friends, In 2 Charts, TECHCRUNCH, July 29, 2013, available at https://techcrunch.com/2013/07/29/whylabor-unions-and-silicon-valley-arent-friends-in-2-charts/ (accessed June 28, 2018); Richard Berman, Honey, I Shrunk the Union, WALL ST. J., April 12, 2017, A13 (restaurant sector); The United Auto Workers Lose Again, Wall St. J., Aug. 7, 2017, A16 (the South). 


\section{Regulation}

A late $20^{\text {th }}$ century trend in favor of deregulation which had bolstered the discretion available to public company executives ended in the 2000s. ${ }^{348}$ Regulatory pressure on business intensified during Barack Obama's presidency. ${ }^{349}$ A double back in favor of deregulation appears to be underway with Donald Trump. Astute political clairvoyance would be needed to predict accurately the legacy of this latest change of course.

Post-financial crisis bankers dialled back risk in response to new regulations, primarily associated with the enactment of the Dodd-Frank Act of $2010 .{ }^{350}$ For many apprehensive about dangers the financial sector pose to the wider economy, the trend has been welcome but does not suffice. The fear is that the intensity of regulatory supervision will weaken as the 2008 crisis fades from memory, opening the door for banks to return to destructive free-wheeling pre-financial crisis ways. ${ }^{351}$ The solution put forward by various critics of mega-banks has been to break them up. For instance, in 2013 and again in 2015 Senators Elizabeth Warren and John McCain co-sponsored bills proposing a restoration of the Glass Steagall split between commercial and investment banking activities. ${ }^{352}$ Neither bill made substantial headway but the 2016 Republican and Democratic Party platforms both called for reinstatement of the Glass Steagall Act. ${ }^{353}$ Political discussion of bank breakups

\footnotetext{
$348 \quad$ Supra notes 188-91 and related discussion.

349 Supra notes 192-94 and accompanying text.

$350 \quad$ Supra notes 204-05 and related discussion.

$351 \quad$ John C. Coffee, Systemic Risk After Dodd-Frank: Contingent Capital and the Need for Regulatory Strategies Beyond Oversight, 111 CoLUM. L. REV. 795, 821 (2011).

352 Peter Eavis, Senators Introduce Bill to Separate Trading Activities From Big Banks, N.Y. Times, July 12, 2013, B3; WiLliam D. Cohan, Why Wall StreEt MatTERs 69 (2017).

353 Edward Robinson, The Taming of Wall Street, Bus. WK., Aug. 1, 2016, 33.
} 
continued after the election. Donald Trump said in a 2017 interview “( $\mathrm{t})$ here's some people that want to go back to the old system, right? So we're going to look at that."354

The tougher regulation of banks that would be involved with a break-up would be out of character for a Trump administration that has thus far adopted a deregulatory orientation. Trump said on the campaign trail in 2016 "I would say 70 percent of regulations can go. It's just stopping businesses from growing." 355 A year into his presidency, Trump claimed“(w)e have undertaken the most extensive regulatory reduction ever conceived." 356 In fact, cases where active regulations have been stripped clean off the books have been rare. ${ }^{357}$ Nevertheless, rule-making has tailed off dramatically. ${ }^{358}$ Executive orders and executive branch agency directives have additionally scaled back numerous planned regulatory actions. ${ }^{359}$ Critics of regulation favorably disposed toward a lighter touch approach have also been appointed to lead several federal agencies. ${ }^{360}$ Somewhat quixotically, given Trump's bank breakup ruminations, the supervisory style of banking regulators has become less abrasive and the Treasury Department has spelled out plans for adopting a relaxed stance in the many areas where Dodd Frank offers discretion. ${ }^{361}$ Then again, Trump did call Dodd-

354 Andrew Ross Sorkin, Wall Street Shudders As Trump Muses, N.Y. TIMES, May 2, 2017, B1.

355 O'Keefe, supra note 196.

356 Barney Jopson, Trump's Bonfire of Red Tape Proves a Slow Burn, Fin. TIMES, Jan. 30, 2018, 6 .

357 Id.; Trump v. the Rule Book, ECONOMIST, Oct. 14, 2017, 61.

358 Trump v. the Rule, supra note 357; Greg Ip, Key Issue for Court: The Administrative State, Wall ST. J., July 12, 2018, A2.

359 Gerald F. Seib, Trump's Deregulatory Juggernaut Is Rolling, W ALL ST. J., Oct. 31, 2017, A2; Binyamin Appelbaum \& Jim Tankersley, Red Tape Losing Its Grip, Firms Ante Up, N.Y. TIMES, Jan. 2, 2018, A1.

$360 \quad$ Applebaum \& Tankersley, supra note 359.

361 Turn of the Wheel, ECONOMIST, June 17, 2017, 73; Matthew Goldstein \& Stacey Cowley, Casting Wall Street as Victim, Trump Leads Charge on Deregulation, N.Y. TIMES, 
Frank a "disaster", vowed after taking office to "do a big number" on it and indicated overregulation had left the financial industry "devastated and unable to properly serve the public." ${ }^{362}$

It is unclear at present whether the deregulatory push by the Trump administration will constitute a mere hiatus in a larger pro-regulatory trend or is the beginning of a deregulation pattern akin to that in operation as the $20^{\text {th }}$ century came to a close. ${ }^{363}$ Future election results will likely do much to dictate which direction things go. Absent an unlikely wholesale regulatory bonfire, however, governmental rule-making should remain a meaningful constraint for public company executives for the foreseeable future.

\section{Competition}

As the $21^{\text {st }}$ century got underway, it appeared to some that intensifying competition in the economy had evolved into a form of "supercapitalism". 364 The competitive pressure businesses face is still widely hyped. On the other hand, the influence wielded by powerful incumbents, particularly in the tech sector, is capturing attention to an extent unknown since the managerial capitalism era ended.

A popular theory is that "business is more competitive than ever", which translates into "a hyper-competitive world in which established giants are constantly being felled by the forces of disruption." 365 A team of analysts from the influential management consultancy McKinsey wrote in 2016 “(i)ncumbents that have long focused on perfecting their industry

Nov. 28, 2017, B1; Ben McLannahan \& Barney Jopson, US Banks Applaud Trump's Shift in Tone on Regulation, FIN. TIMES, Feb. 22, 2018, 6.

362 Goldstein \& Cowley, supra note 361; Shearing and Shaving, ECONOMIST, Feb. 11, 2017, 59.

363 Trump v. the Rule, supra note 357.

$364 \quad$ Supra note 227 and accompanying text.

365 Out With the Old, ECONOMIST, Dec. 17, 2016, 64. 
value chains are often stunned to find new entrants introducing completely different ways to make money", meaning "many business leaders live in a heightened state of alert." 366 As was the case both in the late 1990s and the 2000s, the internet is seen as a primary catalyst for intensifying competition. ${ }^{367}$ With the popularity of smartphones expanding the internet's reach and with apps making it easier to reach consumers directly, ${ }^{368}$ in the words of Google economist Hal Varian, “(c)ompetition is a click away, so competitive advantage can erode quickly." 369 Accordingly, then, cumbersome "corporate giants increasingly struggle with the competition from highly networked and agile startup companies." 370

The development of computer-based technology that facilitates the sharing of information and ideas via virtual networks is a related technical innovation fostering competitive pressure. An otherwise well-positioned firm can quickly find itself under siege by upstart rivals that are using social media successfully to increase awareness of their products and services, to engage in effective targeted marketing and to improve relations with partners in their supply chains. ${ }^{371}$ By virtue of the same technology a powerful brand can be damaged in minutes as news spreads rapidly of a product fault, consumer complaints or apparent ethical lapses. ${ }^{372}$ For senior executives, social media also means, as the president of

366 Angus Dawson, Martin Hart \& Jay Scanlan, The Economic Essentials of Digital Strategy, MCKinsEY Q., (2016), issue \#2, 32, 33, 41.

367 Supra notes 221-22, 225-26 and related discussion.

368 Betsy Morris, What the iPhone Wrought, WALL ST. J., June 24, 2017, B3.

369 Hal Varian, There Is No Hope of a Quiet Life in the Age of Disruption, FIN. TIMES, Oct. 4, 2016, 13

370 Erik P. M. Vermeulen, Corporate Governance in a Networked Age, 50 WAKE FOREST L. REV. 711, 714 (2015).

$371 \quad$ Santiago Chaher and James David Spellman, Corporate Governance and Social Media: A Brave New World for Board Directors, Private SECTOR OPInION, \#27, 1, 1 (2012). 372 Saeed Rohani \& Sharmin Attaran, Social Media: New Challenges and Opportunities for Corporate Governance, 11 INT'L. J. DISCL. \& Gov. 366, 368 (2014); Labour of Love, ECONOMIst, May 26, 2018, 64; Kenneth Hilario, Campbell, Hershey Among Most Reputable U.S. Companies. Why That Matters, PHILADELPHIA BUS. INQUIRER, April 17, 2018, available 
an executive coaching firm said in 2018, “(e)verything you do, everything you say and everything you write can and will be parsed and evaluated by everybody." 373 The increased scrutiny helps to explain why CEO dismissals precipitated by ethical lapses increased 36 percent between 2011 and $2016 .^{374}$

A detrimental public backlash has always been a risk for public company executives. Due to social media, however, the cycle can now kick into operation much more quickly. The primary share price decline Pacific Gas \& Electric Co. suffered due to 1987 revelations of groundwater contamination of water in Hinkley, California occurred when Erin Brockovich, a hit movie about litigation arising from the incident, was released in $2000 .{ }^{375}$ The contrast is stark with a public relations challenge Starbucks faced in April 2018 when two black men were arrested in a Philadelphia Starbucks store following a dispute about bathroom access. Within two days, the company, mindful of calls for a boycott prompted by widespread circulation on Twitter of a video of the incident, announced it would close its stores for an afternoon in May to provide anti-bias training for its 175,000 employees. ${ }^{376}$

at https://www.bizjournals.com/philadelphia/news/2018/04/17/cpb-campbell-hershey-hsyreptrak100-reputable.html (accessed August 2, 2018) ("Consumers now have more power over brand equity because of social media where a trending topic or hashtag can impact a company").

373 John D. Stoll, The Lesson From Intel: It's a New Era for CEOs, WALL ST. J., June 23, 2018, B1.

$374 \quad$ Id.

375 Joe Maiellano, Ethical Case Study: $P G \& E$ and Hinkley CA, LinkEDIN, Aug. 8, 2017, available at https://www.linkedin.com/pulse/ethical-case-study-pge-hinkley-ca-joe-maiellano (accessed August 2, 2018).

376 Rachel Abrams, Starbucks Will Close 8,000 Stores For Training, N.Y. TIMES, April 18, 2018, A11. 
It might seem that given technological trends there is little room to question the notion that challenges by rival firms weigh heavily on the minds of corporate executives. ${ }^{377} \mathrm{~A}$ potent counter-narrative has emerged, however, that challenges the notion that upstarts are engaging in the regular felling of corporate giants. ${ }^{378}$ As Senator Warren said in 2016, there are fears "today, in America, competition is dying." 379 The President's Council of Economic Advisers indicated in a 2016 report "(w)hile there are many benefits of competition for consumers and workers, competition appears to be declining in at least part of the economy." 380 The Economist concurs, arguing "the obvious conclusion is that the American economy is too cosy for incumbents." 381 There have even been suggestions that America could be returning to the oligopolistic market conditions that prompted John Kenneth Galbraith to turn to countervailing powers to explain why the mid- $20^{\text {th }}$ century business sector was performing well despite considerable muting of the discipline associated with competition from rivals. ${ }^{382}$ Economist Tyler Cowen claimed in a 2017 book where he said American society had become counterproductively complacent “(w)e're coming uncomfortably close to that static, conformist caricature of the 1950s oligopolistic business

377 Lucy Kellaway, My New Rule of Competition Begins With a War on Talent, Fin. Times, Oct. 19, 2015, 14 ("Disrupt or be disrupted is the cliché of the moment and no one dares question it.")

378 Out With the Old, supra note 365; Carl Shapiro, Antitrust in a Time of Populism, unpublished working paper, 2-4 (2017).

379 Brent Kendall, Elizabeth Warren Says Competition “Dying," More Merger Scrutiny Needed, WSJ.COM BLOGS - WASHINGTON WIRE, June 29, 2016, available at https://blogs.wsj.com/washwire/2016/06/29/elizabeth-warren-says-competition-dying-moremerger-scrutiny-needed/ (accessed June 15, 2018).

380 Benefits of Competition and Indicators of Market Power, COUNCIL OF ECONOMIC ADVISERS ISSUE BRIEF, Spring 2016, 4.

381 Too Much of a Good Thing, ECONOMIST, March 26, 2016, 23.

382 Supra notes 76, 78, 82-83, 108 and related discussion. 
life where the relative status of the major companies just doesn't change that much over time. $" 383$

Ironically, given that the internet has been seen as a primary catalyst for intensifying competition, high-tech has become the major source of fears about the anti-competitive accumulation of market power. History can account for the apparent contradiction, with the competitive dynamics in the tech sector having changed dramatically recently. As the Economist said in 2016 “(i)n the 1990s Silicon Valley was a playground for startups. It is now the fief of a handful of behemoths." 384

Apple, Alphabet (the parent company of search engine Google), Amazon, Facebook and Microsoft stand out as purveyors of market power in the tech world in that they have each built up and now control platforms that users are highly dependent upon, akin to customers of ostensibly rapacious railroads in the late $19^{\text {th }}$ and early $20^{\text {th }}$ centuries. ${ }^{385}$ These dominant firms benefit from and exploit powerful "network effects" associated with their platforms - for a customer switching to a competing platform few use is a self-defeating strategy - that operate as powerful barriers to entry to potential rivals. ${ }^{386}$ Nevertheless, these firms are not easing off, avoiding difficult decisions and enjoying a "quiet life" in the manner traditionally associated with enterprises that dominate an industry with oligopolistic

\footnotetext{
383 Tyler Cowen, The Complacent Class: The SElf-Defeating Quest FOR THE AMERICAN DREAM 75 (2017).
}

$384 \quad$ Out With the Old, supra note 365.

385 Don Clark \& Robert McMillan, Giants Tighten Grip on Internet Economy, WALL ST. J., Nov. 6, 2015, B1.

386 Jason Furman, Beyond Antitrust: The Role of Competition Policy in Promoting Inclusive Growth, Searle Center Conference on Antitrust Economics and Competition Policy, Sept. 16, 2016, 17, available at https://obamawhitehouse.archives.gov/sites/default/files/page/files/20160916_searle_confere nce_competition_furman_cea.pdf (accessed June 15, 2018); Grep Ip, The Antitrust Case Against America's Technology Behemoths, WALl ST. J., Jan. 17, 2018, A1; Taming the Titans, ECONOMIST. Jan. 20, 2018, 11. 
features. ${ }^{387}$ The New York Times has said of Apple, Alphabet/Google, Amazon, Facebook and Microsoft that none has

"slowed down investing intended to further expand its area of control — for instance, Google keeps investing in search, Facebook is still spending heavily to create new social-networking features, and Amazon remains relentless in creating new ways to let people shop. At the same time, they are all locked in intense battles for new markets and technologies." 388

Moreover, an oligopolistic quiet life seems unlikely for tech sector executives any time soon. The Economist, despite its warnings about the coziness of the American economy, has said that with China's tech industry being on course for parity with America's in 10 to 15 years "(f)or Silicon Valley, it is time to get paranoid." 389

Moving beyond the tech sector, available data tend to confirm that even if the competitive pressure under which businesses operate has eased off since the late 1990s, today's public company executives have good reason to be more apprehensive than their 1950s and 1960s counterparts. The turnover rate with large business enterprises indicates, for instance, that the market environment is more dynamic than it was during the managerial capitalism era. With Fortune 500 companies, 57 percent of those on the 1995 list were gone by 2015 as compared with only 45 percent of 1955 companies having exited by $1975 .^{390}$ Concentration levels calculated taking into account for a wide range of industrial sectors both the number of companies operating and the market share of the biggest firms reveal a similar

387 On the quiet life those in an oligopolistic position may well seek, see Marianne Bertrand \& Sendhil Mullainathan, Enjoying the Quiet Life? Corporate Governance and Managerial Preferences, 111 J. POL. ECON. 1043, 1047 (2003).

$388 \quad$ Farhad Manjoo, The Upside Of Bowing to Big Tech, N.Y. TIMES, Nov. 2, 2017, B1.

389 Chinese Tech v. American Tech, ECONOMIST, Feb. 17, 2018, 69.

390 Alan Murray, Myth-Busting the Fortune 500, FoRTUNE, June 15, $2015,14$. 
pattern. Measures of concentration increased 45 percent across industries between 1995 and 2015 but were still 18 percent lower in 2015 than $1975 .{ }^{391}$ It follows that even if executives of public corporations need not be as fearful of competitors as they were as the $20^{\text {th }}$ century drew to a close, market power does not insulate executives of dominant firms from competitive pressure to the same extent as in the mid- $20^{\text {th }}$ century.

\section{CONCLUSION}

New corporate governance controversies crop up regularly, with debates being sustained by a corporate governance reform "industry" operating out of the shareholder community, academia and professional advisory firms that has a vested interest in keeping change permanently on the agenda. ${ }^{392}$ For the corporate governance industry, the 1950 s and 1960s could be construed as a source of embarrassment. This was an era of "loyalty to the company," 393 with corporate scandals being rare. This was also an era, however, where neither boards nor shareholders played a prominent role in fostering managerial accountability. Boards and shareholders monopolize present day corporate governance discourse, with proposed solutions to concerns about managerial accountability usually being channelled through adjustments to these two internal governance mechanisms. Yet, while boards and shareholders were a governance afterthought during the heyday of managerial capitalism restraint was the norm for corporate executives.

This article has sought to resolve the governance-related paradox of 1950s and 1960s managerial accountability by drawing upon an intellectual construct from that era, namely

391 Kathleen M. Kahle \& René M. Stulz, Is the US Public Corporation in Trouble?, 31 J. ECON. PERSP. 67, 72 (2017).

392 Marcel Kahan \& Edward Rock, Symbolic Corporate Governance Politics, 94 BosTON UNIV. L. REV. 1997, 1998 (2014).

393 EDMUnd P. LEARNED, DAVID N. UlRICH \& DONALD R. BOOZ, EXECUTIVE ACTION 48 (1951). 
John Kenneth Galbraith's notion of countervailing power. From that departure point, we have considered the manner in which three "external" accountability mechanisms - unions, competition from rivals and governmental regulation - operated both at the time and in subsequent decades. Borrowing from Galbraith to understand corporate governance better must be done with some care. He was interested primarily in constraints applicable to corporations rather than management, partly because he assumed executives would seek to foster corporate growth so as to increase their personal power and influence rather than exploit the discretion available to them in a narrowly personal manner. ${ }^{394}$ Nevertheless, the discipline which unions and governmental regulation imposed on public companies and their executives during the middle decades of the $20^{\text {th }}$ century do help to explain why managerial wrongdoing was a rarity.

This article, by considering developments in the 1950s and 1960s, has demonstrated through historical evidence why it is beneficial analytically to think of corporate governance in terms of external as well as internal accountability mechanisms. No attempt has been made to offer a thoroughgoing analysis of external constraints. Unions, competition from rivals and governmental regulation are only a few examples of external accountability mechanisms potentially relevant for public company executives. Some additional candidates were mentioned briefly in the Introduction, namely the market for corporate control, auditors, rating organizations and the media. ${ }^{395}$ There are others as well, with capital market discipline being one. If access to capital is tight, otherwise free-wheeling executives will have to modify, postpone or even abandon their more ambitious schemes. It so happens that for big public companies during the 1950s and 1960s the effect would have been modest in practice. Such firms usually had ample cash on hand due to being "awash in profits" as a result of their

\footnotetext{
$394 \quad$ Supra notes 99-101 and accompanying text.

395 Supra notes 5-7 and related discussion.
} 
market power and the buoyant economy. ${ }^{396}$ Nevertheless, in other contexts, capital markets can be a potent check on managerial discretion.

As well as drawing upon history to underscore the importance of external accountability mechanisms in relation to corporate governance, this article has focused on the present day to illustrate why this insight is particularly pertinent now. As internal accountability mechanisms both boards and shareholders have become substantially more robust since the middle decades of the $20^{\text {th }}$ century. It is likely, however, with both that limits on their potency are coming into view. In the case of boards, there are few obvious structural moves left to enhance monitoring capabilities. As for shareholders, hedge funds have emerged since 2000 as a meaningful source of public company discipline but hedge fund activism may have peaked. Index trackers, seemingly the next "big thing" in the shareholder universe, insist they are not mere "professional snoozers" ${ }^{\text {"397 }}$ but their business model suggests that it is unlikely they will be exercising substantial control over public company executives anytime soon. Given these trends, with respect to the analysis of corporate governance the time is ripe to factor in external mechanisms as fully as internal mechanisms.

396 MizRUCHI, supra note 96, 10; see also supra notes 32, 108-11 and accompanying text; Wells, supra note 110, 317-18.

397 On the characterization, see Snaptrap, ECONOMIST, Feb. 11, 2017, 58. 